\title{
Okul Öncesi Eğitiminde Gerçekleștirilen Tasarım STEM Eğitimlerinin Öğretmen ve Veli Görüşleri Açısından Değerlendirilmesi
}

\author{
Zehra Çakır $^{1} \quad$ Sema Altun Yalçın ${ }^{2}$ \\ ${ }^{1}$ Erzincan Binali Ylldırım Üniversitesi, Eğitim Fakültesi, Fen Bigisi Bölümü, ORCID NO: 0000-0003-4585-8214 \\ ${ }^{2}$ Erzincan Binali Ylldırım Üniversitesi, Eğitim Fakültesi, Fen Bigisi Bölümü, ORCID NO: 0000-0001-6349-2231
}

Geliş: 8 Kasım 2020

Kabul:31 Aralık 2020

ÖZ

$\mathrm{Bu}$ araştırma, tasarım temelli STEM eğitiminin okul öncesi öğrencileri üzerindeki gelişimlerine, mühendislik tasarım becerilerine, derse yönelik katılım ve tutumlarına etkisini öğretmen ve veli görüşleri açısından değerlendirilmesi amacıyla yapılmıştır. Araştırmada, nitel araştırma desenlerinden olan durum çalışması kullanılmıştır. Örneklem Doğu Anadolu' nun orta ölçekli bir ilinde 4 ayrı sınıftaki 5-6 yaş grubu 79 öğrenci oluşturmuştur. Her hafta 2 şer saatlik ders diliminde 5 hafta boyunca günlük malzemelerle ve mühendislik tasarımı için özel olarak tasarlanmış robotik legolarıyla STEM eğitimleri 5 uzman rehberliğinde verilmiştir. Veri toplama araçlarında Öğretmen Gözlem Formu ve Veli Gözlem Formu kullanılmıştır. Araştırma sonucunda, okul öncesi dönemde verilen tasarım temelli STEM eğitiminin öğretmen ve veli gözlemleri doğrultusunda öğrencilerin iletişim kurma, sosyalleşme, farklı bakış açıları geliştirme, üretmeye yönelik başarma motivasyonu sağlama, olumlu tutumlar gösterme, özgüveni artırma ve mühendislik tasarımı becerisini geliştirme gibi farklı becerileri elde etmelerini sağladığı tespit edilmiştir. Öğretmenlerde ve velilerden alınan görüşler birbiri ile uyumlu ve destekler sonuçlar vermiştir.

Anahtar Kelimeler: STEM eğitimi, Okul öncesi eğitim, Tasarım, Tutum

\section{Evaluation of Design STEM Education in Preschool Education in Terms of Teachers and Parents' Views}

\begin{abstract}
This study was conducted to evaluate the effect of design-based STEM education on the development of preschool students, engineering design skills, participation and attitudes towards the lesson in terms of teachers and parents' opinions. The case study, which is one of the qualitative research designs, was used in the study. The sample consisted of 79 students in the 5-6 age group in 4 different classes in a medium-sized city of Eastern Anatolia. STEM trainings were given under the guidance of 5 experts with daily materials and robotic legos specially designed for engineering design for 5 weeks in 2 hours of class each week. Teacher Observation Form and Parent Observation Form were used in data collection tools. As a result of the research, the design-based STEM education given in the preschool period enables students to acquire different skills such as communication, socialization, developing different perspectives, motivation to produce, showing positive attitudes, increasing self-confidence and developing engineering design skills in line with the observations of teachers and parents. has been determined. The opinions received from the teachers and parents gave results that were compatible and supportive with each other.
\end{abstract}

Key Words: STEM education, Preschool education, Design, Attitude 


\section{Giriş}

Gelişen dünyamızda bilim ve teknoloji alanındaki ilerlemelerde giderek hız kazanarak değişim göstermektedir. Bu değişimlerle 21.yy bireyinin sahip olması gereken becerilerde etkilenmektedir (Yıldırım ve Selvi, 2017). Bu beceriler arasında en önemlilerini ülkelerin ekonomik durumlarını göz önüne alıp geleceğin işleri raporunda da belirtildiği gibi yaratıcılık, analitik düşünme, problem çözme, işbirliği ve iletişim kurma olarak belirtilmektedir (Akgündüz ve Akpınar, 2018; Yıldırım, 2020). Dolayısıyla bu becerilerin kazandırılmasında eğitim alanlarında dizayn ve teknoloji alanlarında güncel paradigmalara gidilmesi zorunludur. $\mathrm{Bu}$ paradigmalardan biri STEM eğitim yaklaşımıdır (Yıldırım, 2018). STEM, işbirlikçi bilgi, beceri ve inançları içerir (Meyrick, 2011). STEM, Science (Bilim), Technology (Teknoloji), Engineering (Mühendislik) ve Mathematics (Matematik) kavramlarının baş harflerinin kısaltılmasıyla bu disiplinlerin birbirleriyle entegre edilerek günlük yaşamla ilişkilendirilmiş olan bir eğitim yaklaşımıdır (Çakır, Altun Yalçın ve Yalçın, 2018; Yıldırım ve Türk, 2018). STEM eğitimini Bybee (2010), okul öncesinden itibaren başlanarak 12' nci sınıfa kadar matematik, bilim tabanlı mühendislik ve teknoloji entegre edilerek öğretilen bir yaklaşım şeklinde tanımlamaktadır. STEM' in Türkiye için çıkarımlarını Çepni (2017) araştırmasında ülkemizin STEM eğitimine ilgisi PISA ve TIMMS sınavlarında gösterilen öğrenci başarısızlığının sebepleri aranırken olduğunu belirtmiştir. PISA; her üç yılda bir Ekonomik İşbirliği ve Kalkınma Teşkilatı tarafından düzenlenen dünyanın en kapsamlı tarama araştırma sınavıdır. Birçok ülkenin katıldığı bu araştırma 15 yaş grubu olan temel eğitimi tamamlamış öğrencilerin gerçek hayata ne denli hazır olduklarını tespit etmek için yapılır (PISA, 2012). TIMSS ise Uluslarası Eğitim Başarılarını Değerlendirme Kuruluşu tarafında dört yılda bir düzenlenen öğrencilerin matematik ve fen başarılarını ölçmeye yönelik hazırlanan bir araştırma çalışmasıdır (Kırgız ve Koyuncu, 2016). Yıldırım (2016), PISA / TIMSS gibi uluslararası karşılaştırma çalışmaları ile STEM eğitiminin ilkeleri arasında anlamlı bir ilişki olmasının yanı sıra öğrencinin okuldaki başarısına ve tutumuna yönelik etkisinin olumlu olduğunu belirtmektedir.

Okul öncesi eğitim; çocuğun doğumundan temel eğitime gelinceye kadar ki süreyi kapsayan, çocuğun gelecek yaşamında önemli bir rol oynayan; beden, dil, duygusal, sosyal, zihinsel ve psikomotor becerileri gelişimlerinin büyük kısmının verilen eğitimlerle şekillenerek tamamlandığı eğitim ve gelişim sürecidir (Aral vd., 2015). Günümüzde okul öncesi dönemdeki çocuklar mühendis, problem çözücü, lider, bilim insanı, yaratıcı gibi devasa bir potansiyele 
sahip bireyler olarak ifade edilmektedir (Hadzigeorgiou, 2002). Okul öncesi dönem öğrenmenin en hızlı olduğu dönemdir. Okul öncesi eğitim, çocukların sosyal kuralları öğrenmesini ve sosyal birer birey olarak yetişmelerine katkı sağlar (Tepeli ve Y1lmaz, 2012). Dolayısıyla çocuklara bu dönemde kazandırdığımız yaşantılar gelecekte hayata bakış açılarını büyük ölçüde etkilemektedir. Bu da bir ülkenin kaliteli ve üretken bireylere sahip olabilmesi açısından oldukça önemlidir (Mutlu vd., 2012). Tam bu noktada STEM eğitiminin, kalıcılığını ve etkililiğini devam ettirmesini sağlamak amacıyla okul öncesi dönem itibariyle başlanması en doğru karar olacaktır (Çepni, 2017). Okul öncesi dönemde yapılacak olan STEM çalışmalarında çocukların analitik düşünme, gerekli araç ve gereçleri kullanabilme ve bilimsel süreç becerilerini kullanabilme gibi deneyimler kazanmasına katkı sağlanır (Gropen et al., 2011; Akgündüz ve Akpınar, 2018). Bunların yanı sıra okul öncesinde STEM eğitimi çocuklara buluş yapma, özgüven duygusunu geliştirme, teknolojik bilgi edinme ve yeniliklere açık olma becerileri kazandırır (Morrison, 2006). Son yıllarda, okul öncesi dönemde verilen eğitim müfredatında, teknoloji ve mühendislik kavramları giderek artan bir öneme sahip olmuştur. Robotik, bireylerin okul öncesi dönemde hem $\mathrm{T}$ (teknoloji) hem de $\mathrm{M}$ (mühendislik) kavramlarıyla uğraşmaları için eğlenceli ve somut bir ortam sunmaktadır. Fen, teknoloji, mühendislik ve matematik ile ilgili konuların çocuklara okul öncesi dönemde kavratılması halinde, bireyin ilerde STEM' le ilgili olumlu kararlar alma olasılığını artırdığg tespit edilmiştir (Diamond and Lee, 2011). Çepni (2017), Amerika' da yapılan çalışmalarda STEM eğitimlerinin ilkokul seviyesinde verilmeye başlandığında çocuklar üzerinde olumlu etkiler bıraktığını fakat ilerleyen zamanlarda bu bireylerin meslek seçimlerinde STEM alanlarını tercih etmedikleri görülmüştür. Bu da STEM eğitiminin daha temel seviye olan okul öncesi dönemde verilmesi gerekliliğini ortaya çıkarmış ve bu alan üzerinde çalışmalara başlanılmıştır (Allen, 2016; Çepni, 2017).

STEM entegrasyonunda önemli bir diğer nokta mühendislik disiplinidir. Mühendislik kavramı günümüzde bilimsel kavrayış ve matematiksel analiz gibi akademik disiplinlerin tanımı olarak ifade edilmektedir. Mühendislikte oluşturulan ürünler bir tasarımdır. Bu tasarım süreci uygulamalar yapılırken aşamalar halinde sırasıyla gerçekleşmektedir. Problemin tanımlanması, ihtiyaçların belirlenmesi, olası çözümlerin geliştirilmesi, en iyi çözümün seçilmesi, prototipin yapılması, çözümü test etme, sunma, revize etme ve kararın tamamlanması şeklindedir (Çepni, 2017). Okul öncesinde STEM eğitimine yönelik araştırmalara bakıldığında ortaokul ve lise kademelerine göre çok daha az çalışma olduğu görülmektedir (Uğraş, 2017). Amerika' da yapılan araştırmalar sonucu başarılı bir STEM eğitimi için yoğunluk gösterilmesi 
gereken dönem anaokulundan 3. Sınıfa kadar verilecek STEM eğitimin önemini açıkça vurgulamaktadır (Çepni, 2017). Yine Polat ve Bardak (2019), Türkiye'de STEM alanında yapılan faaliyetlerde erken çocukluk ile ilgili kısa bilgiler ve tartışma ile biten araştırmaların bu alanda olan eksikliğin bir göstergesi olduğunu vurgulamışlardır.

$\mathrm{Bu}$ araştırmada amaç okul öncesi öğrencilere uygulanan tasarım temelli STEM eğitiminin öğretmen ve veli açısından öğrenciye yönelik etkilerinin değerlendirilmesidir. Eğitime yönelik öğrenci tutumunu, tepkisini, öğrenciye sağladı̆̆ı katkısını (problemi çözebilme, psikomotor becerileri geliştirme, farklı bakış açısıyla düşünebilme, mühendislik tasarım becerilerini geliştirme ve ürün tasarlayabilme gibi), öğrenci düzeyine ve eğitim sistemine uygunluğunu öğretmen ve veli tarafından değerlendirmektir.

\section{Yöntem}

\section{Araştırma Modeli}

Araştırmada, nitel bir araştırma desenlerinden olan durum çalışması kullanılmıştır. Durum çalışmaları desenleri içerisinden ise programın etkilerine dayalı durum deseni kullanılmıştır. Durum çalışması, bir konunun belli bir zaman dilimi içinde ayrıntılı bir şekilde incelenmesini sağlayan betimsel bir nitel araştırma yaklaşımıdır (Creswell, 2002).

\section{Çalışma Grubu}

Eğitim, Doğu Anadolu' da orta ölçekli bir ilin anaokulunda yer alan 4 ayrı okul öncesi sınıfında yapılmıştır. Toplamda 5-6 yaş aralığındaki 79 öğrenci yer almaktadır. Öğrencilerin tamamı daha önce STEM eğitimi almadan ve veliler ile okul yönetiminden izin alınarak yapılmıştır.

\section{Veri Toplama Araçları}

$\mathrm{Bu}$ çalışma kapsamında veri toplama aracı olarak "STEM Uygulamaları Öğretmen Mülakat Formu" ve "STEM Uygulamaları Veli Mülakat Formu" kullanılmıştır. Bu yarı yapılandırılmış mülakat formu araştırmacı tarafından geliştirilmiştir. Öğretmen mülakat formu toplamda 15 açık uçlu soru ve veli mülakat formu da 6 açık uçlu sorudan oluşmaktadır. Yarı yapılandırılmış mülakat formlarının geçerliliğinin sağlanmasında, literatür taraması yapılarak araştırmacı tarafından oluşturulan soruların taslak hâli anlaşılırlık ve amaca uygunlu açısından STEM eğitimi alanında uzman olan 3 akademisyene sunulmuştur. Uzman görüşleri doğrultusunda forma son hali verilmiştir. Formlar 4 öğretmen ve 4 veliye uygulanarak veriler toplanmıştır. 


\section{Veri Analizi}

Çalışma sonucunda elde edilen veriler içerik analizine tabi tutulmuştur. $\mathrm{Bu}$ analiz yöntemlerinde araştırmacı tarafından yapılan görüşmelerden sınırlandırılmış kodlar ortaya çıkarılır ve ilgili kategoriler oluşturulur. Daha sonra bu kategorilerin esastaki realiteyi belirten ifadeleri ortaya konulmaya çalışılmaktadır (Yıldırım ve Şimşek, 2013). Yapılan görüşme verileri bir kayıt altına alınarak veriler yazıya dönüştürülmüş ve içerik analizinin aşamalarına uygun olarak analiz edilmiştir. Veri analizlerinin geçerlik ve güvenirlik boyutunda oluşturulan kod ve kategoriler 4 ayrı uzman tarafından analiz edilerek sonuçlar birleştirilmiştir. Nitel veri analiz güvenilirliği kısmında $\mathrm{P}=(\mathrm{NaX} 100) / \mathrm{Na}+\mathrm{Nd}(\mathrm{P}$ : Uyuşum yüzdesi, $\mathrm{Na}$ : Uyuşum miktarı, Nd: Uyuşmazlık miktarı) formülü yapılarak güvenirlik değeri \%75 bulunmuştur. Sonuca göre kodlayıcılar arası güvenilirliğin \%70 üstü, \% 80'e yakın olması nedeniyle güvenilir olduğu söylenebilir (Arastaman vd., 2018).

\section{Süreç}

Çalışmada okul öncesi dönemde STEM eğitiminin uygulanması için öncelikle alan taraması yapılmış, eğitim ortamlarının hangi felsefe ve uygulama yaklaşımları hedef alınarak öğrenme basamak ve ortamlarının kullanıldığı araştırılmıştır. Uygulamaların seçiminde bazı noktalara özellikle dikkat edilmiştir. Bunlar; uygulanan etkinliklerin STEM eğitimi özelliklerini kesinlikle tam anlamıyla barındırması, çocukların bulunduğu döneme yönelik araştırmacı ve meraklı gelişim özelliklerine uygu olan farklı ve yeni tasarımlar, ürünler oluşturabilecekleri heyecanını verebilecek özellikte olması, karşılaşacakları problemlere yönelik sorunları kendi başlarına fikirler üreterek ya da fikir alış verişlerinde bulunarak çözebilecekleri nitelikleri içermesi, psikomotor becerilerinin gelişimlerine katk1 sağlayabileceği düzeyde olmasına özellikle dikkat edilmiştir. Etkinlikler, farklı uygulama alanlarını içinde bulunduracak şekilde özellikle günlük yaşamın her alanında bulunabilen basit malzemelerden ve mühendislik tasarımı için özel üretilmiş legolarından oluşturulmuştur. Öğrencilere 5 hafta boyunca alanında uzman araştırmacıların rehberliğinde tasarım temelli STEM eğitimi verilmiştir. Her hafta önceden uzmanlar tarafından belirlenen uygulamaların yapılması için dersin öğretmeninin yardımıyla dört kişiyi geçmeyen gruplar oluşturulmuştur. Gruplar oluşturulduktan sonra haftanın belirlenen uygulamasına yönelik öğrencilere açıklamaları çok uzatmadan kısa öz bilgiler verilerek malzemeler tanıtılmıştır. Daha sonra her grup kendi üyeleriyle ortak katılım gösterilmesine dikkat edilerek tamamen kendi yaratıcılıklarına bırakılıp tasarımlar oluşturmaları istenmiştir. 


\section{Etik Bilgi}

Erzincan Binali Yıldırım Üniversitesi İnsan Araştırmaları Etik Kurulu Kararı ile 01.09.2020 tarihli ve 07/05 sayılı bir çalışmadır. Araştırmada veri toplamak üzere seçilen örneklem grubundaki gönüllü bireyler onam formu imzalanarak konu hakkında bilgilendirildi. Bilimsel Araştırma ve Yayın Etiği' ne aykırı işlemlerin hiçbiri yapılmamış ve Yükseköğretim Kurumları Bilimsel Araştırma ve Yayın Etiği Yönergesindeki tüm kurallara uyulmuştur.

\section{Bulgular}

$\mathrm{Bu}$ bölümde, görüşme formu sonucunda elde edilen nitel verilere ilişkin öğretmen ve veli görüşme bulgularına yer verilmiştir.

Öğretmenlerle yapılan görüşme soruları ve analizi

Tablo 1.

“Verilen STEM Ĕ̈itimi sırasında ögrencilerin tutumları nasıldı? İlk başta, süreç ortasında ve sonundaki etkisi nasıldı?” sorusuna ilişkin ögretmen görüşleri

\begin{tabular}{llr}
\hline Kategori & \multicolumn{1}{c}{ Kod Adı } & Frekans (F) \\
\hline \multirow{3}{*}{ Tutum } & Heyecan & 5 \\
& Beğenmek & 5 \\
& Dikkat çekici & 5 \\
\hline \multirow{2}{*}{ Dönütler } & Veli görüşleri & 2 \\
& Eğitimi almayanların görüşleri & 1 \\
\hline \multirow{2}{*}{ Eğitim Süreci } & Verimli & 1 \\
& Aktif katılım & 1 \\
& Uzun süreli & 1 \\
& Farklı eğitim & 4 \\
\hline \multirow{2}{*}{ Zihinsel Aktivite } & Hayal gücü & 2 \\
& Farklı bakış açısı & 3 \\
& Sorular sorma & 1 \\
\hline \multirow{2}{*}{ Tasarım Becerisi } & Farklı yöntemler deneme & 3 \\
& Tasarlama-çizimler & 6 \\
& Kendi başına üretme & 2 \\
Toplam & Birlikte yapma & 1 \\
\hline
\end{tabular}

Tablo 1' de görüşme sonucu öğretmenlerin soruya yönelik cevaplarına yer verilmiş ve 5 ayrı kategori ortaya çıkmıştır. Tutum kategorisinde; heyecanlı $(f=5)$, beğenmek $(f=5)$ ve dikkat çekici ( $\mathrm{f}=5)$ kodları bulunmaktadır. Bu kategoride öğretmenler, çocukların tutumlarını duygusal açıdan ilk başlarda tam bilemedikleri için şaşkınlık ve heyecan duyarak yaklaştıklarını ve süreç boyunca da bir sonraki her etkinliği merakla bekleyip yaptıklarını, özelliklere 
yaptıkları robotların hareket etmesini çok beğendiklerini, kendi ürünlerini oluşturmak çok hoşlarına gittiğini, etkinliklerin malzemeleri de dahil çok ilgi ve dikkatlerini çektiğini belirtmişlerdir.

Dönütler kategorisinde; veli görüşleri $(f=2)$ ve eğitimi almayanların görüşleri $(f=1)$ kodları bulunmaktadır. Bu kodlarda öğretmenler etkinliklerden sonra velilerden farklı dönütler alarak sevindiklerini belirtmişlerdir. Bunlar, çocukların o günkü yapılanları ailelerine heyecanla anlattıklarını ve bu durumun velileri çok mutlu ettiğini, öğretmenleri arayarak teşekkür ettiklerini, çocuklarında olan değişimleri söylemişlerdir. Bazı velilerin çocuğunun okulla ilgili yapılanları ilk kez heyecanla anlattığını, benzer etkinlikleri kendi yaratıcılığını kullanarak evde yapmaya çalıştığını, farklı şeyler denemeye yöneldiğini belirtmişlerdir.

Eğitim süreci kategorisinde; verimli ( $f=1)$, aktif katılım $(f=1)$, farklı eğitim $(f=4)$ ve uzun süreli eğitim ( $\mathrm{f}=1$ ) kodları bulunmaktadır. Bu kategoride eğitimin çocuk için ilgi ve farklı bakış açılarını geliştirdiğini ve güzel olduğunu ama bu sürecin zaman ya da gün olarak daha fazla olmasının çocuğun aktif katılımını daha çok sağlayacağını ve daha verimli geçebileceğini belirten ifadelere yer verilmiştir. Ayrıca eğitimin çocuklarda bıraktığı tutumları, normal eğitimle kıyaslamışlardır. STEM eğitiminin çocuklar tarafından çok farklı bulunduğunu, özellikle materyallerinin normal verilen eğitimden daha farklı olması (motor, pil, anahtar vb.) ilgileri ve beğenilerini çok çektiğini belirtmişlerdir. Tasarım sonunda elde edilen ürünün hareket etmesi çocuk için çok farklı geldiği ve mutlu olduklarını belirtmişlerdir.

Zihinsel aktivite kategorisinde; hayal gücü $(\mathrm{f}=2)$, farklı bakış açısı $(\mathrm{f}=3$ ) ve sorular sorma ( $\mathrm{f}=1)$ kodları bulunmaktadır. Bu kodlarda öğretmenler etkinliklerin çocuğun hayal gücünü geliştirdiğini, oyun zamanlarında aldıkları eğitime benzer şeyler yaptıklarını ve onları zihinlerinde hareket ediyormuş gibi davrandıklarını belirtmişlerdir. Eğitimin çocukların farklı düşünceler tasarlamalarına katkı sağladığını ve farklı bakış açıları kazandırdığını belirtmişlerdir. Çocukların her hafta bu etkinliklerin yapılacağı gün öğretmenlerine, eğitmenlerin ne zaman geleceklerini, acaba bugün hangi etkinliği yapılacağı gibi sorular sorduklarını belirtmişlerdir.

Tasarım becerisine etki kategorisinde; farklı yöntemler deneme $(\mathrm{f}=3)$, tasarım-çizimler $(\mathrm{f}=6)$, kendi başına üretmek ( $\mathrm{f}=2$ ), farklı robotlar yapma ( $\mathrm{f}=1$ ) ve birlikte yapma $(\mathrm{f}=1)$ kodları bulunmaktadır. Bu kategoride öğretmenler etkinliklerde çocukların kendi başlarına bir şeyler üretmelerinin çok hoşlarına gittiğini, etkinliklerden sonra oyuncak legolarıyla benzer robotlar yapmaya başladıklarını, yaptıkları ürüne yönelik farklı yöntem ve düşünceler geliştirdiklerini, resim yaparken bile çizimlerinin konusunun değiştiğini (robot ya da araba) belirtmişlerdir. 
Eğitmenlerin takıldıkları sırada rehberlik ederek birlikte sorunu gidermenin çocukları mutlu ettiğini belirtmişlerdir.

Tablo 2.

“Verilen STEM Eğitimi sırasında karşılaşılan problemler nelerdir? Nasıl çözümler üretildi? ” sorusuna ilişkin ögretmen görüşleri

\begin{tabular}{llr}
\hline Kategori & \multicolumn{1}{c}{ Kod Adı } & Frekans (F) \\
\hline \multirow{2}{*}{ Karşılaşılan Problemler } & Zaman & 2 \\
& Zorluklar & 5 \\
\hline \multirow{2}{*}{ Çözüm Üretme } & Çocuklara anlatılması & 1 \\
& Grup etkinlikleri & 1 \\
\hline \multirow{3}{*}{ Olumlu Etki } & Aktiflik & 2 \\
& Akademik başarı & 2 \\
& Liderlik & 1 \\
& Yaratıcılık & 1 \\
\hline \multirow{2}{*}{ Oneriler } & Uzun ve aşamalı eğitim & 4 \\
& Grup kişi sayısını azaltma & 2 \\
\hline Toplam & & 21 \\
\hline
\end{tabular}

Tablo 2' de görüşme sonucu öğretmenlerin soruya yönelik cevaplarına yer verilmiş ve 4 ayrı kategori ortaya çıkmıştır. Karşılaşılan problemler kategorisinde; zaman (f=2) ve zorlanma $(\mathrm{f}=5)$ kodları bulunmaktadır. $\mathrm{Bu}$ kategoride öğretmenler eğitimler sırasında karşılaşılan bazı sorunlardan bahsetmişlerdir. Bunlar, ders saatlerinin kısa ve gruptaki kişi sayısının fazla olması herkesin etkinliğe katılabilmesini bazen etkilediği, mühendislik tasarımı için özel tasarlanmış robotic legoların yapımında biraz zorlanıldığını, sürecin başında henüz bazı davranışlar oturmadığı için öğrencilerin sabırsız davranarak birbirini bekleme konusundaki kurallara uymada sıkıntı olması tarzı problemlerden bahsedilmiştir. Robotic legolarının yapımında zorlanılmasının sebebi ise çocukların bu özel tasarlanmış legolarla ilk kez karşılaşmış olmalarıdır.

Çözüm üretme kategorisinde; çocuklara anlatılması ( $\mathrm{f}=1$ ), grup etkinlikleri ( $\mathrm{f}=1)$ kodları bulunmaktadır. Bu kodlarda öğretmenler, etkinliklerin grupça yapılması nedeniyle bazı öğrencilerin girişim gösteremedikleri ve bunu fark edince o çocuklara olayı daha net anlatarak yeniden yapmaları için fırsat verdiklerini ve sorunları çok güzel bir şekilde giderdiklerini belirtmişlerdir.

Olumlu etki kategorisinde; aktiflik $(\mathrm{f}=2)$, akademik başarı $(\mathrm{f}=2)$, liderlik $(\mathrm{f}=1)$ ve yaratıcılık ( $\mathrm{f}=1)$ kodları bulunmaktadır. Bu kodlarda öğretmenler verilen eğitimin çocuklar üzerinde bıraktığı olumlu etkilerden bahsetmişlerdir. Bu etkiler; çocuğun birebir kendisi yapmasına yani işin içine girmesine fırsat sunmasını, çocuğun ilgisini çekerek katılımı daha çok artırması, akademik başarılarını ve yaratıcılık becerilerini geliştirmesi, bazı pasif kalan 
öğrencilerin içlerinde yatan liderlik becerilerini ortaya çıkarmasına katkı sağladığını belirtmişlerdir.

Öneriler kategorisinde; uzun ve aşamalı eğitim $(\mathrm{f}=4)$ ile grup kişi sayısını azaltma ( $\mathrm{f}=2$ ) kodları bulunmaktadır. Bu kodlarda öğretmenler problemlere ve eğitime yönelik öneride bulunmuşlardır. Grup sayılarının artırılması herkesin etkinliğe katılmasını kolaylaştıracağını, eğitimlerin uzun süreli ve birden çok aşamalar halinde devamının olmasına yönelik görüşler belirtilmiştir.

Tablo 3.

“Verilen STEM Ĕğitimi Sırasında Öğrencilerin Karşılaştı̆̆ı Problemler Nelerdi? Nasıl Çözdüler? ” Sorusuna İlişkin Öğretmen Görüşleri

\begin{tabular}{llr}
\hline Kategori & \multicolumn{1}{c}{ Kod Adı } & Frekans (F) \\
\hline \multirow{2}{*}{ Duygu } & Zevk alma & 2 \\
& İtina gösterme & 1 \\
\hline \multirow{2}{*}{ Öğrenci Problemleri } & Yoktu & 2 \\
& Zorlanma & 3 \\
\hline \multirow{2}{*}{ Zihinsel Beceri } & Fikir alışverişi & 3 \\
& Parça bütünleştirme & 1 \\
\hline Cinsiyet & Kizlar daha iyi & 1 \\
& Ayrım olmama & 1 \\
\hline Zaman & Kisa süreli & 1 \\
& Uzun süreli & 1 \\
\hline Öğrenci Becerileri & Klavuzlara bağl kalmama & 2 \\
& Ürün ortaya koyma & 2 \\
\hline \multirow{2}{*}{ Çözüm Yolu } & Grup kişi sayisını azaltma & 1 \\
& Rehber yönlendirmeleri & 1 \\
\hline Toplam & & 23 \\
\hline
\end{tabular}

Tablo 3' te görüşme sonucu öğretmenlerin soruya yönelik cevaplarına yer verilmiş ve 7 ayrı kategori ortaya çıkmıştır. Duygu kategorisinde; zevk alma ( $\mathrm{f}=2)$ ve itina gösterme $(\mathrm{f}=1)$ kodları bulunmaktadır. Bu kodlarda bazı öğretmenler eğitimde öğrenciler tarafından herhangi bir problemle karşılaşılmadığını etkinlikleri çok beğenip zevk alarak yaptıklarını özellikle araba tarzı etkinliklerde erkekler daha iyi yapar tarzı bir ayrıma gidilmeksizin kız öğrencilerinin daha bir itina göstererek yaptıklarını belirtmişlerdir.

Öğrenci problemleri kategorisinde; yoktu $(\mathrm{f}=2)$ ve zorlanma $(\mathrm{f}=3)$ kodlar1 bulunmaktadır. Bu kodlarda eğitim esnasında bazı etkinliklerde öğrencilerin yaşadıkları zorluklar belirtilmiştir. Bunlar, ilk başlarda öğrencilerin tek başlarına yardım olmadan yapamamaları, gruplardaki kişi sayısı çokluğu nedeniyle her çocuğun katılamaması ve robotik legolarının küçük olması nedeniyle birleştirmede biraz sıkıntı yaşadıklarını belirtmişlerdir. Fakat zorlanmış olsalar bile çocukların bu legolarla farklı robotlar tasarlayarak farklı düşünme ve mantık yürütme becerilerini sergiledikleri belirtilmiştir. 
Zihinsel beceri; fikir alışverişi $(\mathrm{f}=3$ ) ve parça bütünleştirme ( $\mathrm{f}=1$ ) kodları bulunmaktadır. Bu kodlarda öğretmenler çocukların eğitimlerde oluşan problemlere karşı fikir alışverişi yapmaya başladıklarını ve yeni fikirler ürettiklerini belirtmişlerdir.

Cinsiyet kategorisinde; kız da erkek de iyi ( $\mathrm{f}=1$ ) ve ayrım olmama $(\mathrm{f}=1)$ kodları bulunmaktadır. Bu kodlarda öğretmenler etkinliklerin araba, gemi tarzı erkeklere hitap eden robotlardan oluşmasının yapım aşamasında çocuklar tarafından cinsiyet ayrımı tarzı bir ilgisizlik oluşmadığını her iki cinsiyette de ilgiyle yapıldığını hatta bazı öğretmenler kızların daha da iyi yaptıklarını gözlemlediklerini ifade etmişlerdir.

Zaman kategorisinde; kısa süreli ( $\mathrm{f}=1)$ ve uzun süreli ( $\mathrm{f}=1)$ kodları bulunmaktadır. $\mathrm{Bu}$ kodlarda öğretmenler eğitimin daha uzun süreli olmasının çocuklar için daha iyi olacağını ifade etmişlerdir.

Öğrenci becerileri kategorisinde; klavuzlara bağlı kalmama (f=2) ve ürün ortaya koyma $(\mathrm{f}=2)$ kodları bulunmaktadır. $\mathrm{Bu}$ kodlarda öğretmenler çocukların robotik etkinliklerinde verilen klavuzlara bağlı olarak yaparken zorlandıklarını ve klavuza bağlı olmadan kendileri de tasarlayabileceklerini söylediklerinde çocukların tasarımlarda daha güzel ve kolayca ortaya ürünler çıkardıklarını, kendi fikirlerini ve arkadaşlarının fikirlerini alıp kafasındaki fikir dağınıklığı gidererek tek başına ürünler ortaya koyduklarını belirtmişlerdir.

Çözüm yolu kategorisinde; grup kişi sayısını azaltma ( $\mathrm{f}=1)$ ve rehber yönlendirmeleri $(\mathrm{f}=1)$ kodları bulunmaktadır. Bu kodlarda öğretmenler bahsedilen problemlere yönelik olarak yapılan çözüm ve çözüm yollarından bahsetmişlerdir. Bu problemlerde rehberleri açıklayıcı yönlendirmeleriyle sorunun giderildiğini ve imkân doğrultusunda grup kişi sayısını azaltılmasının gerektiğini belirtmişlerdir.

Tablo 4.

“STEM Ĕ̆itimi Öğrencilerin Düzeyine Uygun Muydu? Değilse Neden? Neler Yapılmalı?” Sorusuna İlişkin Öğretmen Görüşleri

\begin{tabular}{llr}
\hline Kategori & \multicolumn{1}{c}{ Kod Adı } & Frekans $(\mathbf{F})$ \\
\hline \multirow{2}{*}{ Zihinsel } & Hayal dünyasını geliştirme & 1 \\
& Hafizayı geliştirme & 1 \\
\hline \multirow{2}{*}{ Duygu ve Düşünce } & İyi & 2 \\
& Çok uygun & 4 \\
\hline \multirow{2}{*}{ İletişimim-Bilgi } & Kitaplar & 1 \\
& Bilgisayar & 1 \\
\hline Beceri & Teknolojik çağ & 1 \\
& Yaratıcılık & 1 \\
\hline \multirow{2}{*}{ Eğitim Etkisi } & İnce motor kasları & 1 \\
& Birebir katılım & 1 \\
& Hazırlık & 1 \\
\hline
\end{tabular}




\section{Toplam} 19

Tablo 4' de görüşme sonucu öğretmenlerin soruya yönelik cevaplarına yer verilmiş ve 5 ayrı kategori ortaya çıkmıştır. Zihinsel kategorisinde; hayal dünyasını geliştirme ( $\mathrm{f}=1)$ ve hafızayı geliştirme $(\mathrm{f}=1)$ kodları bulunmaktadır. Bu kodlarda öğretmenler eğitimin birkaç özellik dışında çocukların düzeyine genel olarak uygun olduğunu belirterek çocuğun hafızasını ve hayal dünyalarını geliştirdiğini belirtmişlerdir.

Duygu ve düşünce kategorisinde; iyi $(\mathrm{f}=2)$ ve çok uygun $(\mathrm{f}=4)$ kodları bulunmaktadır. Burada bazı öğretmenler eğitimin çok uygun olduğunu 1 öğretmen ise uygun olduğunu fakat bazı etkinliklerin yardımsız direk çocuğun yapacağı şekilde olmadığını ve süreci daha uzun tutarak tamamen çocuğa bırakılmasının daha uygun olacağını vurgulamıştır. Öğretmenler verilen eğitimin çocuk için çok iyi olduğunu, normal kendi etkinliklerinden çok daha fazla ilgiyle karşıladıklarını içeren duygu ve düşüncelerin, belirtmişlerdir.

İletişim-bilgi kategorisinde; kitaplar ( $\mathrm{f}=1)$, bilgisayar $(\mathrm{f}=1)$ ve teknolojik çağ $(\mathrm{f}=1)$ kodları bulunmaktadır. $\mathrm{Bu}$ kodlarda öğretmenler günümüzde bilgisayarın yaygın olduğu teknolojik çağamız sebebiyle öğrencilerinin normal kitaptan yaptırdıkları etkinlikleri sıkıcı ve basit bulduklarını bu sebeple verilen eğitimin çocuklarda önemli bir olumlu etki yaptığını belirtmişlerdir.

Beceri kategorisinde; yaratıc1lk $(\mathrm{f}=1)$ ve ince motor kasları ( $\mathrm{f}=1)$ kodlar1 bulunmaktadır. Bu kodlarda bir öğretmen verilen eğitimde bazı motorlu etkinliklerin yapımı çocukların ince motor kasları henüz çok gelişmediği için birebir yapılabileceği etkinlikler olmayacağını rehberlik ve daha uzun süreyle yapılmasının daha uygun olacağını, yaratıcılıklarını daha çok geliştireceğini belirtmiştir.

Eğitim etkisi kategorisinde; birebir katılım $(f=1)$, hazırlık $(f=1)$ ve donanım $(f=1)$ kodları bulunmaktadır. Bu kodlarda öğretmenler, eğitimin öğrencilere birebir etkinliğe katılma fırsatı sunmasını ayrıca bir sonraki etkinliğe daha iyi bir donanım ve hazırlık içinde istekle gelmelerini sağladığını, normal eğitimde aldıkları renk-sayı tarzı konuları artık basit görmeye başladıklarını göz önüne alarak uygunluğunu belirtmişlerdir.

Tablo 5.

"STEM Ĕ̆itimi Sürecinde Öğrencilerin (Eğitimi Alan Ve Almayan) Tepkisi Yani Davranışları Nasıldı?” Sorusuna İlişkin Öğretmen Görüşleri

\begin{tabular}{llr}
\hline Kategori & Kod Adı & Frekans(F) \\
\hline \multirow{2}{*}{ Öğrenci Tepkisi } & Olumlu & 6 \\
& Soru sorma & 1 \\
\multirow{2}{*}{ Duygu } & İcat yapma & 2 \\
\hline
\end{tabular}




\begin{tabular}{llr}
\hline & Diğer sınıfları bilmeme & 3 \\
Eğitimi Almayan Öğrenciler & Haberi olmama & 3 \\
\hline Toplam & & 18 \\
\hline
\end{tabular}

Tablo 5' te görüşme sonucu öğretmenlerin soruya yönelik cevaplarına yer verilmiş ve 3 ayrı kategori ortaya çıkmıştır. Öğrenci tepkisi kategorisinde olumlu ( $f=6)$, soru sorma $(f=1)$ ve icat yapma $(\mathrm{f}=1)$ kodları bulunmaktadır. Bu kodlarda öğretmenler eğitim süreci boyunca öğrencilerin olumlu tepkilerine yer vermişlerdir. Etkinliklere ilgiyle bakıp yaptıklarını, güzel ve değişik tasarımlar icat ettiklerini belirtmişlerdir.

Duygu kategorisinde; merak ( $\mathrm{f}=2$ ) ve hayıflanma ( $\mathrm{f}=1$ ) kodları bulunmaktadır. $\mathrm{Bu}$ kodlarda öğretmenler öğrencilerin eğitim sürecine yönelik duygularını belirtmişlerdir. Etkinliklerde hareket etmesi öğrencileri çok şaşırttığı, her hafta merakla beklediklerini hatta bazı sebeplerden ötürü o hafta yapılan etkinliğe katılamayan öğrencilerin ailelerine keşke gitseydim şeklinde hayıflanarak baskı yaptıklarını ifade etmişlerdir.

Eğitimi almayan öğrenciler kategorisinde; diğer sınıfları bilmeme $(f=3)$ ve haberi olmama (f=3) kodları bulunmaktadır. Bu kodlarda öğretmenlerden bazıları verilen eğitime karşı diğer sınıftaki öğrencilerin de tepkilerinin ne olduğuna yönelik olarak her sınıf kendi içinde çalıştıkları için sınıflar arasında birbirlerinin yaptıklarından haberdar olmadıklarını belirtmişlerdir.

Tablo 6.

"STEM Eğitiminin Öğrencilere Bir Katklsı Olduğunu Düşünüyor Musunuz? Olduysa Bunlar Nelerdir?” Sorusuna İlişkin Öğretmen Görüşleri

\begin{tabular}{llc}
\hline Kategori & Kod Adı & Frekans(F) \\
\hline \multirow{2}{*}{ Meslek seçimi } & Mühendislik & 2 \\
& Astronot & 1 \\
\hline \multirow{2}{*}{ Duygu ve Düşünce } & İlgi çekici & 3 \\
& Şaşırmak & 2 \\
\hline \multirow{2}{*}{ Davranış-Tutum } & Robot çizimleri & 1 \\
& Evde tekrarlama & 3 \\
& Oyuna yansıtma & 1 \\
& Kiz çocukları & 1 \\
\hline \multirow{2}{*}{ Eğitim Faydaları } & Farkındalılk & 1 \\
& El becerisi & 3 \\
& Başarı duygusu & 1 \\
& Özgüven artırma & 1 \\
& Korkuları azaltma & 1 \\
& Eğitim uygunluğu & 1 \\
Toplam & Hayatlarına girme & 1 \\
\hline
\end{tabular}


Tablo 6' da görüşme sonucu öğretmenlerin soruya yönelik cevaplarına yer verilmiş ve 4 ayrı kategori ortaya çıkmıştır. Meslek seçimi kategorisinde; mühendislik ( $\mathrm{f}=2)$ ve astronot (f=1) kodlar bulunmaktadır. En fazla frekans mühendislik koduna aittir. Bu kodlarda öğretmenler verilen eğitimin öğrencilerin meslek seçimine yönelik etkisinden bahsetmişlerdir. Bazı çocukların mühendisliğe yönelik ilgi ve becerilerinin STEM eğitimi sayesinde çok iyi geliştiğini belirtmişlerdir. Yine eğitimden sonra başka bir öğrencinin astronot olmak istediğini belirtmişlerdir.

Duygu ve düşünce kategorisinde; ilgi çekici ( $\mathrm{f}=3$ ) ve şaşırmak ( $\mathrm{f}=2$ ) kodları bulunmaktadır. Bu kodlarda öğretmenler verilen eğitimin öğrencilere sağladığı katkılara yönelik düşüncelere yer verilmiştir. Dikkatlerini çekerek ilgilerini artırdığını ve oluşan ürünleri şaşkınlıkla karşılayıp çok güzel olduklarını belirtmişlerdir.

Davranış-tutum kategorisinde; robot çizimleri ( $\mathrm{f}=1)$, evde tekrarlama $(\mathrm{f}=3)$, oyuna yansıtma ( $\mathrm{f}=1)$ ve kız çocukları $(\mathrm{f}=1)$ kodları bulunmaktadır. Bu kodlarda öğretmenler verilen eğitimin öğrencilerde davranış ve derse olan tutumlarına yönelik sağladığı katkılardan bahsetmişlerdir. Öğretmenler, eğitimden sonra velilerden çocuklarının okulda yaptıklarını evde heyecanla anlattıklarını, evde tekrar bulduğu malzemelerle, kağıt ve şişlerden robotlar yapmaya çalıştı̆̆ını, bunun da sadece çocuğu değil aileleri de mutlu ettiğini içeren dönütler aldıklarını belirtmişlerdir. Yine verilen eğitimdeki etkinliklerin araba ya da robot tarzı olması cinsiyet ayrımı gözetmediğini hatta kız öğrencilerin bazı etkinliklerde erkeklerden daha iyi yaptıklarını, öğrencilerin yapılanları resimlerine yansıdığını, çizimlerinin robotlar tarzında çizimlere döndüğünü, oyunlarında robotlar yaparak bunları konuşturduklarını, hayal dünyalarını bu şekilde zenginleştirdiğini belirten ifadelere yer vermişlerdir.

Eğitimin faydaları; farkındalık ( $f=1)$, el becerisi $(f=3)$, başarı duygusu ( $f=1)$, özgüven $\operatorname{artırma~}(f=1)$, korkuları azaltma $(f=1)$, eğitim uygunluğu $(f=1)$, hayatlarına girme $(f=1)$ ve mesleki tercih $(\mathrm{f}=2)$ kodları bulunmaktadır. En fazla frekans el becerisi geliştirme ve ilgili alan mesleklerine yönelme kodlarına aittir. Bu kodlarda öğretmenler eğitimin öğrenciye sağladığ1 faydaları belirtmişlerdir. Verilen eğitimler sonrasında bazı öğrencilerin mühendisliğe yönelik bilgi ve becerilerinde gelişmeler olduğunu, ilgili alana yönelik mühendislik ve astronot gibi meslekleri seçmek istediklerini belirttiklerini, bir şeyler yaparak kendi ürünlerini ortaya koymaları, başaramama korkularını azalttığını, başarabilme duygusunun verdiği destekle özgüvenlerini artırdığını belirtmişlerdir. Ayrıca eğitimin çocuk için uygunluğunu belirterek yapılan etkinliklerin resim yapma yeteneklerini de geliştirdiğini, ailelerine kadar yapılanlar 
çocuklar tarafından aktarılarak yavaş yavaş hayatlarına bu tarz etkinlikler girmeye başladığını ve bir nevi bir farkındalık oluşturulduğunu ifade etmişlerdir.

Tablo 7.

“STEM Ĕ̆itimi Öğrencilere Verilmeli Mi? Neden?” Sorusuna İlişkin Öğretmen Görüşleri

\begin{tabular}{llr}
\hline Kategori & \multicolumn{1}{c}{ Kod Adı } & Frekans(F) \\
\hline \multirow{2}{*}{ Öğrenciye Yönelik Katk1 } & Kendini geliştirme & 3 \\
& Oyun konusu değişimi & 1 \\
\hline \multirow{2}{*}{ Duygu-Düşünce } & Çok güzel & 3 \\
& Teknoloji & 1 \\
\hline & Verilmeli & 4 \\
Eğitim Hakkındaki Görüşler & Okul öncesi eğitim değişimi & 2 \\
& Öğretmen donanımı & 2 \\
\hline Toplam & Müfredat & 19 \\
\hline
\end{tabular}

Tablo 7' de görüşme sonucu öğretmenlerin soruya yönelik cevaplarına yer verilmiş ve 3 ayrı kategori ortaya çıkmıştır. Öğrenciye yönelik katkı kategorisinde; kendini geliştirme ( $f=3)$ ve oyun konusu değişimi (f=1) kodları bulunmaktadır. Bu kodlarda öğretmenler, okul öncesi programının kendini geliştirmesi ve değiştirmesi gerekliliğini belirterek STEM eğitiminin verilmesini, çocukların hayal güçlerini çok geliştirdiğini ve bunun belirtisini eğitimlerden sonra oynadıkları oyun konularının değişiminden anlaşıldığını, yapılan etkinliklerde daha özgüvenli bir şekilde hareket ettiklerini belirtmişlerdir.

Duygu-düşünce kategorisinde; çok güzel ( $\mathrm{f}=3$ ) ve teknoloji $(\mathrm{f}=1)$ kodları bulunmaktadır. En fazla frekans çok güzel koduna aittir. Bu kodlarda öğretmenler, eğitimin okul öncesi öğrencilere verilmesi gerektiğine yönelik olarak teknolojiyi barındırmasını da göz önüne alarak çok güzel ve dikkat çekici bir eğitim olduğuna yönelik duygu ve düşüncelerini ifade etmişlerdir.

Eğitim hakkındaki görüşler kategorisinde; verilmeli ( $f=4)$, okul öncesi eğitim değişimi $(\mathrm{f}=2)$, öğretmen donanımı ( $\mathrm{f}=2)$ ve müfredat $(\mathrm{f}=2)$ kodları bulunmaktadır. $\mathrm{Bu}$ kodlarda öğretmenlerin hepsi eğitimin okul öncesinde verilmesi gerektiği görüşünde hem fikirdir. Verilmesinde başlıca nedenleri olarak da öğretmenlerin donanım açısından bazen yetersiz kalması ve bu eğitimle kendini geliştirebilmesi, müfredata koyularak okul öncesi eğitimin değiştirilmesine ve böylece klasiklikten çıkılması gerektiğini, müfredatta olması eğitim için gereken malzemelerin temini konusunda sıkıntı yaşamayacaklarını ve daha iyi olacağını ifade etmişlerdir. 
Tablo 8.

“STEM Ĕ̆itimi Öğrencilere Hangi Konular Kapsamında Verilmeli? ” Sorusuna İlişkin Öğretmen Görüşleri

\begin{tabular}{llr}
\hline Kategori & \multicolumn{1}{c}{ Kod Adı } & Frekans (F) \\
\hline \multirow{2}{*}{ Konular } & Fen & 4 \\
& Matematik & 1 \\
& Türkçe & 2 \\
& Oyun dersi & 2 \\
\hline \multirow{2}{*}{ Öğretmen Yetersizliği } & Araştırma & 1 \\
& Doğa & 1 \\
\hline \multirow{2}{*}{ Ŏğretmen Eğitimi } & Fen & 1 \\
\hline Toplam & Hizmetiçi eğitim & 3 \\
\hline
\end{tabular}

Tablo 8' de görüşme sonucu öğretmenlerin soruya yönelik cevaplarına yer verilmiş ve 4 ayrı kategori ortaya çıkmıştır. Konular kategorisinde; matematik $(f=1)$, Türkçe $(f=1)$ ve oyun dersi ( $\mathrm{f}=1)$ kodları bulunmaktadır. Bu kodlarda öğretmenler STEM eğitiminin okul öncesi dönemde hangi konular kapsamında verilebileceğini ifade eden ders ve kazanımları belirtmişlerdir. Önerdikleri dersler fen deneyleri, fen ve doğa, bilim, günlük yaşam becerileri, hikayeleştirme, okuma-yazma konularında uygulanabileceğini belirtmişlerdir. Genel olarak ise STEM eğitiminin okul öncesi dönemdeki her konu ve etkinlik kapsamında uyarlanabileceği belirtilmiştir.

Öğretmen yetersizliği kategorisinde; araştırma $(\mathrm{f}=1)$, doğa $(\mathrm{f}=1)$, fen $(\mathrm{f}=1)$ ve kodları bulunmaktadır. Bu kodlarda bazı öğretmenler fen, doğa ve araştırmaya yönelik yetersiz olduklarını bu konularda genellikle hep bilindik deneyler yaptıklarını belirterek STEM eğitiminin bu alanlarda yapılmasının önemini belirtmiştir.

Öğretmen eğitimi kategorisinde; hizmetiçi eğitim ( $\mathrm{f}=3$ ) ve uzman ( $\mathrm{f}=1$ ) kodları bulunmaktadır. Bu kodlarda öğretmenler, STEM eğitiminin özellikle okul öncesi öğretmenlere fen konusundaki yetersizliği sebebiyle hizmetiçi eğitimler düzenlenip verilmesi ve bu alanlarda birer uzman konumunda olmaları sağlanması gerektiğini içeren görüşleri belirtmişlerdir. 
Tablo 9.

"Sizce STEM Eğitiminin Verilmesi Iç̧in Gerekli Şartlar Nelerdir (Müfredat, Sinıf, Malzeme vb. Açısından)?” Sorusuna İlişkin Öğretmen Görüşleri

\begin{tabular}{llr}
\hline Kategori & Kod Adı & Frekans (F) \\
\hline \multirow{2}{*}{ Süre } & Zamanla alışma & 1 \\
& Zamanla geliştirme & 1 \\
\hline \multirow{2}{*}{ Uygunluk } & Zaman alması & 1 \\
\hline & Öğrenci düzeyi & 2 \\
& Müfredat & 4 \\
Eğitim Dizaynı & Sınıf ortamı & 3 \\
& Atölye & 1 \\
& Akıl ve zeka oyunları & 1 \\
& MEB desteği & 1 \\
\hline \multirow{3}{*}{ Materyaller } & Öğretmen ilgisi & 1 \\
& Eğitim malzemeleri \\
& Motor, pil, kablo vb. & 1 \\
& Fark etme & 1 \\
\hline \multirow{2}{*}{ Öğrenme } & Yaparak öğrenme & 1 \\
& Hazırbulunuşluk & 1 \\
& Basitten karmaş̧ı̆̆a & 2 \\
& Kavrama & 1 \\
\hline \multirow{2}{*}{ Duygu-Düşünce } & Bilgi & 6 \\
& Verim & 1 \\
\hline \multirow{2}{*}{ Bilimsel Beceri } & Aile etkisi & 1 \\
\hline Toplam & Göz aşinalı̆̆ & 1 \\
\hline
\end{tabular}

Tablo 9' da görüşme sonucu öğretmenlerin alışma ( $\mathrm{f}=1$ ), zamanla geliştirme ( $\mathrm{f}=1)$ ve zaman alması ( $\mathrm{f}=1)$ kodları bulunmaktadır. Bu kodlarda öğretmenler, STEM eğitiminin öğrenci açısından uygunluğuna yönelik olarak her öğrenciye verilebileceğini, ilk başlarda zorlanılsa da bir süre sonra zamanla alışılıp geliştirilebileceğini ve yapabileceklerini ifade etmişlerdir.

Uygunluk kategorisinde; öğrenci düzeyi $(\mathrm{f}=2)$ ve müfredata $(\mathrm{f}=4)$ kodlar1 bulunmaktadır. Bu kodlarda öğretmenler, eğitimin genel olarak öğrenci düzeyi ve müfredat tarzı konularda uygun olduğunu, öğrenci düzeyinin ailede temelde bir eğitim verildiği sürece basitten karmaşığa ilkesi esas alınarak uygun olacağını belirtmişlerdir.

Eğitim dizaynı kategorisinde; sınıf ortamı $(\mathrm{f}=6)$, atölye $(\mathrm{f}=3)$, akıl ve zeka oyunları $(\mathrm{f}=1)$, MEB desteği $(\mathrm{f}=1)$ ve öğretmen ilgisi $(\mathrm{f}=1)$ kodları bulunmaktadır. Bu kodlarda öğretmenler STEM eğitiminin verilmesi için gereken eğitim dizaynlarına yönelik görüşlerini ifade etmişlerdir. Eğitim için gereken malzemeleri stoklayabilecekleri, daha düzenli ve amaca uygun olarak tasarlanmış, çeşitli akıl ve zeka oyunları tarzı materyalleri de barındıran atölye tarzında başka bir sınıf olmasının iyi olacağını belirtmişılerdir. Normal sınıf ortamında çocukların oraya zaten alıştıkları ve çok benimsedikleri için zamanla bazı materyallere alışmış 
olması sebebiyle dikkat çekiciliğini yitirmesi, MEB desteği ile malzemelerin daha kolay elde edileceğini, öğretmenlerin bu konuda ilgili olduğunu bu sebeple güzel sonuçlara ulaşılacağını belirten ifadelere yer verilmiştir.

Materyaller kategorisinde; eğitim malzemeleri ( $\mathrm{f}=1)$, motor $(\mathrm{f}=1)$, pil ( $\mathrm{f}=1)$, kablo vb. $(\mathrm{f}=1)$ ve fark etme $(\mathrm{f}=1)$ kodları bulunmaktadır. Bu kodlarda öğretmenler STEM eğitimi şartlarını malzeme açısından değerlendirmişlerdir. Sonuç olarak da eğitimin verilmesinde malzeme açısından bir sıkıntı olmayacağını, özel bir malzemeye gerek olmadığını yani kolayca ulaşılabilecek düzeyde malzemeleri barındırdığını, kendi etkinliklerinde kullandıkları malzemelerden çok farkı olmadığını, fark olarak pil, motor ve kablo tarzı malzemeleri ilk kez kullandıklarını, eğitimde bazı çocuklar için kullanılan malzemelerin daha büyük bazıları için normal küçük parçalar halinde çocuğun el becerisine göre sunularak yapılabileceğini belirtmişlerdir.

Öğrenme kategorisinde; yaparak öğrenme $(f=1)$, hazırbulunuşluk $(f=1)$, basitten karmaşığa $(\mathrm{f}=1)$, kavrama $(\mathrm{f}=2)$ ve bilgi $(\mathrm{f}=1)$ kodları bulunmaktadır. Bu kodlarda bazı öğretmenler STEM eğitiminin verilebilmesi ve öğrenmede etkisinin olabilmesi için gerekli şartlar arasında çocuğun hazırbulunuşluk düzeyinin de önemli olduğunu vurgulamışlardır. Çocuğun ilgilerine göre etkinliklerin basitten karmaşığa doğru sıralanması gerektiğini, uygulayarak bir fırsat sunmasının fayda sağladığını, çocuğun ailesinden bir bilgi birikimi ile geldiğinde öğretilenleri daha kolay kavrayacağını ve eğitimin daha verimli olacağını aksi durumda ise daha zor kavrayacaklarını ifade etmişlerdir.

Duygu-düşünce kategorisinde; verim ( $f=6)$, aile etkisi $(f=1)$ ve göz aşinalı̆̆ $(f=1)$ kodları bulunmaktadır. $\mathrm{Bu}$ kodlarda öğretmenler, STEM eğitimi için ayrı bir sınıf oluşturulmasının daha güzel olacağını ve farklı sınıfın çocukların malzemelere ya da ortama yönelik göz aşinalığını azaltacağını böylelikle dikkat ve ilgi çekici bulacaklarını, ailenin de çocuğuna verdiği destekle eğitimde verimliliği artıracağını belirtmişlerdir.

Bilimsel beceri kategorisinde; yaratıcılık ( $\mathrm{f}=1)$ ve zekâ açma ( $\mathrm{f}=1)$ kodları bulunmaktadır. Bu kodlarda Stem eğitiminin öğrenciler için uygunluğu dile getirerek her öğrencinin yaratıcılığını geliştirdiği ve zekalarını açtığı belirtilmiştir. 
Tablo 10.

“Sizce STEM Eğitimi Türk Eğitim Sistemine Uygun Mu?” Sorusuna İlişkin Öğretmen Görüşleri

\begin{tabular}{llr}
\hline Kategori & \multicolumn{1}{c}{ Kod Adı } & Frekans (F) \\
\hline \multirow{2}{*}{ Eğitimin Verilme Başlangıcı } & Okul öncesi & 5 \\
& Her düzeyde & 1 \\
\hline \multirow{2}{*}{ Türk Eğitim Sistemine Uygunluk } & İsminin koyulması & 1 \\
& Benzer etkinlikleri barındırma & 1 \\
\hline Toplam & & 12 \\
\hline
\end{tabular}

Tablo 10' da görüşme sonucu öğretmenlerin soruya yönelik cevaplarına yer verilmiş ve 3 ayrı kategori ortaya çıkmıştır. Eğitimin verilme başlangıcı kategorisinde; her düzeyde ( $\mathrm{f}=1)$ ve okul öncesi ( $\mathrm{f}=5$ ) kodları bulunmaktadır. Bu kodlarda bütün öğretmenler STEM eğitiminin Türk eğitim sistemine gayet uygun olduğunu, gelişmek ve diğer gelişmiş ülkelere yetişmek için bu eğitimin her düzeyde verileceğini fakat en uygun dönemin okul öncesi dönemden itibaren başlanması gerektiğini ifade etmişlerdir.

Türk eğitim sistemine uygunluk kategorisinde; isminin koyulması $(\mathrm{f}=1)$ ve benzer etkinlikleri barındırma $(\mathrm{f}=1)$ kodları bulunmaktadır. Bu kodlarda öğretmenler, eğitimin Türk eğitim sisteminde de benzer etkinlikleri barındırdığını ve bu etkinliklerin daha kapsamlı ve birbiri ile entegre edilmiş bir hali bir başlık altında toplanarak isminin konulduğunu belirtmişlerdir.

Tablo 11.

"STEM Etkinliklerinin Okul Öncesi Dönem Çocuklara Uygulanmasını Uygun Buluyor Musunuz? Neden?” Sorusuna İlişkin Öğretmen Görüşleri

\begin{tabular}{llr}
\hline Kategori & \multicolumn{1}{c}{ Kod Adı } & Frekans (F) \\
\hline Zihinsel Aktivite & Fikirleri şekillendirme & 1 \\
& Yaratıcıllk & 2 \\
\hline \multirow{2}{*}{ Ürün } & Mükemmel & 1 \\
& Özgün & 1 \\
& Basit & 1 \\
\hline \multirow{2}{*}{ Faydalar } & Olumlu tepkiler & 1 \\
& Öğrenme & 1 \\
& Özgüven & 1 \\
& Çok uygun & 3 \\
Eğitime Yönelik Görüş & Verimli etkinlikler & 1 \\
& 36 ay grupları & 1 \\
& Kapsam & 1 \\
\hline Toplam & Süreç & 31 \\
\hline
\end{tabular}

Tablo 11' de görüşme sonucu öğretmenlerin soruya yönelik cevaplarına yer verilmiş ve 4 ayrı kategori ortaya çıkmıştır. Zihinsel aktivite kategorisinde; fikirleri şekillendirme $(f=1)$ ve 
yaratıcılık ( $\mathrm{f}=2$ ) kodları bulunmaktadır. Bu kodlarda öğretmenler, STEM eğitiminin öğrenciler için çok uygun bulduklarını ve bunun sebepleri arasında çocukları zihinsel olarak geliştirdiğini ifade etmişlerdir. Çocuklar ne kadar farklı şeylerle karşılaşırsa o kadar farklı düşüncelere sahip olacaklarını, fikirler üretebileceklerini, fikirlerinin bir o kadar şekilleneceğini ifade etmişlerdir. Verilen STEM etkinliklerden sonra çocukların yaratıcılık becerilerinin geliştiğini üstelik artık öğretmenlerin kendi yapacağ 1 bir etkinlikte öğrencilerin çok farklı fikirler sunduğunu ve öğretmenlerini yönlendirdiklerini bir öğretmen ifade etmiştir.

Ürün kategorisinde; mükemmel ( $\mathrm{f}=1)$, özgün ( $\mathrm{f}=1$ ) ve basit $(\mathrm{f}=1)$ kodları bulunmaktadır. $\mathrm{Bu}$ kodlarda öğretmenler, verilen eğitim ile öğrencilerin mükemmel ve özgün ürünler ortaya çıkarmalarını sağlaması sebebiyle verilmesinin uygunluğunu ve belki biraz daha basitleştirilerek de verilebileceğini belirtmişlerdir.

Faydalar kategorisinde; olumlu tepkiler ( $f=1$ ), öğrenme ( $f=1$ ) ve özgüven ( $f=1)$ kodları bulunmaktadır. Bu kodlarda öğretmenler, STEM eğitiminin öğrencilere sağladığı faydaları ifade ederek uygulanmasını istediklerini belirtmişlerdir. Yani eğitime karşı öğrencilerin yapılan etkinliklere yönelik dikkat çekici şaşırtıcı bulduklarını, verilmek istenen konunun basitleştirilerek çocuğun öğrenmesini sağladığını, etkinlik sonunda kendi başlarına bir ürün ortaya koymalarının özgüvenlerini artırdığını ve olumlu tepkiler oluşturduğunu, oyunlarına bile bu ekinlik konularının yansıdığını belirten görüşlere yer vermişlerdir.

Eğitime yönelik görüş kategorisinde; çok uygun $(\mathrm{f}=3)$, verimli etkinlikler $(\mathrm{f}=1), 36$ ay grupları (f=1), kapsam ( $\mathrm{f}=1)$ ve süreç $(\mathrm{f}=1)$ kodları bulunmaktadır. Bu kodlarda öğretmenler, STEM eğitiminin okul öncesi için uygunluğundan bahsederek bazı önerilerde bulunmuşlardır. Eğitim kapsamında farklı etkinlikler barınması ve farklı şeyler yapabileceğini çocuğa öğretmesi sebebiyle çok güzel olduğunu, çocuğun aldığı normal eğitimden bir adım yukarıya çıkardığını ve sağladığı eğitim verimliliği ile çocuğu geliştirdiğini bu yönleriyle de çocuklar için önemli olduğunu belirtmişlerdir. Yapboz etkinliklerinin biraz zor olduğunu fakat genel anlamda yaptıkları için 36 ay gruplarına uygun olduğunu, grup sayılarının daha az olması her çocuğun katılımının daha çok olması açısından iyi olacağını, çocuklara başarma duygusunu verdiğini, eğitim sürecinin başındaki öğrenci tutumlarını ve sonundaki tutumlarını değerlendirdiğinde çok olumlu farklar ortaya koyduğunu ifade etmişlerdir. 
Tablo 12.

"Daha Önce Kendi Yaptı̆̆ınız Etkinliklerde STEM Uygulamış Mıydınız? Bu Konuda Bilginiz Var Mıydı?? Sorusuna İlişkin Öğretmen Görüsleri

\begin{tabular}{llr}
\hline Kategori & \multicolumn{1}{c}{ Kod Adı } & Frekans (F) \\
\hline \multirow{2}{*}{ Benzer Etkinlikler- Materyaller } & Parçalardan oluşan nesneler & 1 \\
& Gruplara ayırma & 1 \\
& Tasarımlar yapma & 1 \\
\hline \multirow{2}{*}{ STEM Uygulamaları } & Bilmeden uygulama & 4 \\
& İsim olarak bilmeme & 2 \\
Toplam & Profesyonel & 2 \\
\hline
\end{tabular}

Tablo 12’ de görüşme sonucu öğretmenlerin soruya yönelik cevaplarına yer verilmiş ve 2 ayrı kategori ortaya çıkmıştır. Benzer etkinlikler-materyaller kategorisinde parçalardan oluşan nesneler $(\mathrm{f}=1)$, gruplara ayırma $(\mathrm{f}=1)$ ve tasarımlar yapma $(\mathrm{f}=1)$ kodları bulunmaktadır. Bu kodlarda öğretmenler, daha önce kendi uyguladıkları etkinliklerin STEM eğitimi ile benzer taraflarını belirtmişlerdir. Özellikle malzeme bakımından benzerlik olduğunu şişe kapağı, pipet gibi malzemelerle araba etkinliğinin bir benzerini önceden yaptıklarını, kendilerinin de yine önceden STEM eğitiminde olduğu gibi sınıfı gruplara ayırarak tasarımlar oluşturduklarını, parçaları bütünleştirerek bir ürün ortaya koyduklarını ifade etmişlerdir.

STEM uygulamaları kategorisinde; bilmeden uygulama $(\mathrm{f}=4)$, isim olarak bilmeme $(\mathrm{f}=2)$, ve profesyonel $(\mathrm{f}=2)$ kodları bulunmaktadır. Bu kodlarda öğretmenler, verilen eğitimden önceki zamanlarda internette karşılaştıkları etkinlikleri uyguladıklarını ve farkında olmadan STEM etkinliklerinden sınıflarında yaptırdıklarını ama bunun STEM olduğunu isim olarak bilmediklerini sonradan öğrendiklerini, STEM eğitiminin daha profesyonel bir halde olduğunu ifade etmişlerdir.

Tablo 13.

"Sizce STEM Eğitiminin Klasik Uygulamalarda Farkı Var Mı? Varsa Nelerdir?” Sorusuna Illişkin Öğretmen Görüşleri

\begin{tabular}{llr}
\hline Kategori & \multicolumn{1}{c}{ Kod Adı } & Frekans (F) \\
\hline Duygu-Düşünce & Eğlenceli & 4 \\
& Çekici & 5 \\
\hline & Hareketli sistemler & 1 \\
\multirow{2}{*}{ Klasik Eğitimden Farkı } & Aktif katılım & 2 \\
& Planlı & 3 \\
& Yapıllandırma & 1 \\
& Basit olmama & 2 \\
\hline \multirow{2}{*}{ Yöntem-Teknik } & Gösterip yaptırma & 1 \\
& Düşünmeye yöneltme & 1 \\
\multirow{2}{*}{ STEM Eğitimi Faydaları } & Resimler gösterme & 1 \\
\hline \multirow{2}{*}{ STEM Eğitiminin Yansıması } & Uçuk fikirler üretme & 3 \\
& Öğrenme & 1 \\
\hline
\end{tabular}




\section{Toplam} 31

Tablo 13' te görüşme sonucu öğretmenlerin soruya yönelik cevaplarına yer verilmiş ve 5 ayrı kategori ortaya çıkmıştır. Duygu-düşünce kategorisinde; eğlenceli ( $\mathrm{f}=4)$ ve çekici $(\mathrm{f}=5)$ kodları bulunmaktadır. Bu kodlarda öğretmenler, STEM eğitiminde süreç sonunda hareket eden ürünler çıkardığı için çocuğun dikkatini ve derse olan ilgisini daha çok çektiğini, bu etkinliklerde derslerin daha çok eğlenceli geçtiğini, yapılacak etkinliği tamamen çocuğun yaratıcılığına bıraktığını ve sonunda çok farklı güzel ürünler ortaya çıktığını belirtmişlerdir.

Klasik eğitimden farkı; hareketli sistemler ( $\mathrm{f}=1)$, aktif katılım ( $\mathrm{f}=2)$, planlı $(\mathrm{f}=2)$, yapılandırma $(\mathrm{f}=1)$, birebir katılım $(\mathrm{f}=1)$, basit mama $(\mathrm{f}=2)$, kodları bulunmaktadır. Genel olarak bu kodlarda öğretmenler STEM eğitiminin normal eğitimden farklarını belirten görüşlere yer verilmiştir. Eğitimin klasik eğitime göre işlenişi daha planlı ve daha düzenli ilerlediğini yani normalde sadece bir etkinliği derste yapıp bitirdiklerini fakat STEM de yapılan etkinliği ve konusunu gün içerisinde çocuğa diğer konulara entegre ederek verildiğinde (örneğin, gemi etkinliği o gün yapılıysa hikaye zamanında da gemiyle ilgili konuları okuma, oyun zamanında yine gemiyi katma gibi) daha verimli ve eğlenceli derslerin geçtiğini, etkinliklerde birebir bütün çocukların aktif katılımını sağladığını, sonunda hareket eden ürünler ortaya çıkarması ilgiyi daha artırdığını, çocukların yaratıcılıklarını açığa çıkarmasına fırsat sunarak değişik ve çok güzel ürünler oluştuğunu, normal eğitimdeki gibi etkinliklerin basit ve sıradan olmadığını belirten farklılıkları ifade etmişlerdir.

Yöntem-teknik kategorisinde; gösterip yaptırma ( $f=1$ ), düşünmeye yöneltme ( $f=1$ ) ve resimler gösterme $(\mathrm{f}=1)$ kodları bulunmaktadır. Bu kodlarda STEM eğitiminin çocuğu tamamen düşünmeye yönelttiğini, önceden normal eğitimlerinde yapılacak olan etkinliğin resmini çocuğa gösterip aynısını yapmalarını beklerken STEM de etkinlik konusunun bir modelini sadece gösterip yöneltici sorular sorarak tamamen çocuğun yaratıcılığına bıraktığını ifade etmişlerdir.

STEM eğitimi faydaları kategorisinde; uçuk fikirler üretme $(f=3)$ ve öğrenme $(f=1)$ kodları bulunmaktadır. Bu kodlarda öğretmenler STEM eğitiminin verimli olduğunu, çocuğun yaratıcılık becerilerini geliştirdiğini belirtmişlerdir.

STEM eğitiminin yansıması kategorisinde; hikayeleştirme $(f=1)$ ve oyun $(f=1)$ kodları bulunmaktadır. Bu kodlarda bir öğretmen STEM de yapılan bir etkinlik konusunun gün içinde hikaye zamanı, oyun zamanı gibi alanlara entegre ederek verimliliği artırdığını belirtmiştir. 
Tablo 14.

"STEM Etkinliklerinin Öğrenci Katılımını Artırdığını Düşünüyor Musunuz?” Sorusuna Illişkin Ögretmen Görüşleri

\begin{tabular}{llr}
\hline Kategori & \multicolumn{1}{c}{ Kod Adı } & Frekans(F) \\
\hline & Derse istek & 3 \\
Öğrenci Katılımı & Aktif katılım & 2 \\
& Akılda kalıcılık & 1 \\
& Fark etme & 2 \\
& Aktarma & 2 \\
& Süreç & 1 \\
& Üretme & 2 \\
\hline \multirow{2}{*}{ Etkinlikler } & Robot yapma & 1 \\
& Mancınık yapma & 1 \\
& Robotik lego etkinliği & 1 \\
\hline \multirow{3}{*}{ Duygu } & Hoşlanmak & 4 \\
& Çekingenlik & 1 \\
& Heyecan & 1 \\
\hline \multirow{2}{*}{ Öğrenci Özellikleri } & Enerjisi yüksek & 2 \\
& Lider yapilı & 1 \\
& Cinsiyet & 1 \\
\hline & Özgüven & 1 \\
STEM Eğitimi Faydaları & Uzmanlık & 1 \\
& Değisisim & 1 \\
\hline \multirow{2}{*}{ Öneri } & Pekiştireç & 1 \\
& Sinıf kalabalı̆̆1 & 1 \\
\hline Toplam & Uzun süre & 43 \\
\hline
\end{tabular}

Tablo 14' de görüşme sonucu öğretmenlerin soruya yönelik cevaplarına yer verilmiş ve 6 ayrı kategori ortaya çıkmıştır. Öğrenci katılımı kategorisinde; derse istek ( $\mathrm{f}=3)$, aktif katılım $(\mathrm{f}=2)$, aktarma ( $\mathrm{f}=2)$, akılda kalıcılık $(\mathrm{f}=1)$, üretme $(\mathrm{f}=2)$ ve süreç $(\mathrm{f}=1)$ kodları bulunmaktadır. Bu kodlarda bütün öğretmenler STEM eğitiminin derse yönelik çocukların katılımlarını ve isteklerini artırdığını ifade etmişleridir. Öğrencilerin özellikle etkinlik günlerinde okula daha çok gelmek istediklerini gelemeyen olduğu zaman diğer arkadaşlarının o haftaki etkinliği ona anlattığını, süreç olarak ilk başlarda çocukların çekingen davrandığını fakat sonraları bir şeyler yaptıkça ve bu yaptıkları ürünleri gördükçe katılımın daha çok arttığını, bazı öğrencilerinin derse karşı ilgisizliğini bu eğitimle dikkatlerini çekerek aktif katılımını sağladığını, öğrendiklerini diğer arkadaşlarıyla paylaştığını ve öğrettiğini, anlatılanların akılda kalıcılığını sağladığını ve resim çizimlerine bunları aktarmaya başladıklarını ifade etmişlerdir.

Etkinlikler kategorisinde; robot yapma $(\mathrm{f}=1)$, mancinık yapma $(\mathrm{f}=1)$ ve robotik lego etkinliği ( $\mathrm{f}=1$ ) kodları bulunmaktadır. Bu kodlarda öğretmenler yapılan etkinliklerin öğrencilerin dikkatini ve ilgisini çekerek katılımı artırdığını ifade etmişlerdir.

Duygu kategorisinde; hoşlanmak ( $\mathrm{f}=4)$, çekingenlik ( $\mathrm{f}=1$ ) ve heyecan $(\mathrm{f}=1)$ kodları bulunmaktadır. En fazla frekans hoşuna gitme koduna aittir. Bu kodlarda öğretmenler yapılan 
etkinliklerde öğrencilerin duygularını belirtmişlerdir. Süreç başında çekingen davrandıklarını ama sonradan aktif katılım gösterdiklerini, çok hoşlarına gittiğini, o gün yapılanları arkadaşlarına ve ailelerine heyecanla anlattıklarını ifade etmişlerdir.

Öğrenci özellikleri kategorisinde; enerjisi yüksek $(\mathrm{f}=2)$, lider yapılı $(\mathrm{f}=1)$ ve cinsiyet $(\mathrm{f}=1)$ kodları bulunmaktadır. Bu kodlarda öğretmenler, farklı özellikteki öğrencilerin yapılan etkinliğe yönelik aktif katılım sergilediklerini belirtmişlerdir. Etkinliklerde araba, gemi tarzı erkeklerin daha çok dikkatini çekebileceği düşünülse de kızlar onlar gibi hatta daha çok katılım sağladığını, hareketli ve yüksek enerjili öğrencilerin normalde pek etkinliklere katılmadığını çekici bulmadığını fakat STEM etkinliklerinde ciddi anlamda bir katılım ve beğeni oluştuğunu fark ettiklerini, bazı çocukların içlerinde yatan fark etmediğimiz lider özelliklerini ortaya çıkardığını ifade etmişlerdir.

STEM eğitimi faydaları kategorisinde; özgüven ( $f=1)$, uzmanlık $(f=1)$, değişim $(f=1)$ ve pekiştireç $(\mathrm{f}=1)$ kodları bulunmaktadır. Bu kodlarda bir öğretmen hiperaktif bir öğrencisinin normal derslerde yapılan etkinlikleri pasif bularak katılım göstermediğini fakat STEM etkinliklerine karşı dikkatini çok çektiğini ve ona karşı bu konuda gereken yöneltmeler ve olumlu pekiştireçler vererek çok farklı ürünleri tek başına oluşturduğunu gördüklerini ifade etmiştir. Ayrıca etrafına arkadaşlarını toplayıp yaptıkları hakkında bilgiler vermeye başladığını ve kendini bu alanda bir uzman olarak gördügünü ve bunu ifade ettiği belirtilmiş ve özgüveni artırdığı ifade edilmiştir. Bütün öğretmenler STEM etkinliklerinin öğrenciler üzerinde olumlu değişimler gerçekleştirdiğini ifade etmişlerdir.

Öneri kategorisinde; sınıf kalabalığı $(\mathrm{f}=1)$ ve uzun süre ( $\mathrm{f}=1)$ kodları bulunmaktadır. $\mathrm{Bu}$ kodlarda öğretmenler STEM etkinliklerinde sınıfın kalabalık olması katılımı etkileye bildiği, grupların daha az olması ve daha uzun süreli yapılması verimi daha da artıracağını belirten önerilerde bulunmuşlardır.

Tablo 15.

"STEM Etkinlikleri Öğrencilerin Motivasyonu, Özgüveni Ve Aktifliklerine Karşı Bir Etkisi Olduğunu Düşünüyor Musunuz? Nasıl?” Sorusuna İlişkin Öğretmen Görüşleri

\begin{tabular}{lcr}
\hline Kategori & Kod Ad1 & Frekans(F) \\
\hline Duygu & Mutlu olma & 3
\end{tabular}




\begin{tabular}{llr}
\hline & Güzel & 1 \\
\hline & Dikkat & 1 \\
& Aktiflik & 1 \\
Öğrenciye Etkisi & Aile & 1 \\
& Özgüven & 1 \\
& Olumlu etki & 1 \\
\hline \multirow{3}{*}{ Alternatifler } & Dokunma duyusu & 1 \\
& Uygulama & 1 \\
& Teoriden uzaklaşma & 1 \\
\hline Toplam & & 19 \\
\hline
\end{tabular}

Tablo 15' de görüşme sonucu öğretmenlerin soruya yönelik cevaplarına yer verilmiş ve 3 ayrı kategori ortaya çıkmıştır. Duygu kategorisinde; mutlu olma ( $f=3)$ ve güzel $(f=1)$ kodları bulunmaktadır. $\mathrm{Bu}$ kodlarda öğretmenler STEM eğitiminde yapılan etkinliklerden öğrencilerden memnun ve mutlu olduklarını, hoşlarına gittiğini belirten olumlu duygulardan bahsetmişlerdir.

Öğrenciye etkisi kategorisinde; dikkat ( $\mathrm{f}=1$ ), aktiflik ( $\mathrm{f}=1$ ), aile ( $\mathrm{f}=1)$, özgüven $(\mathrm{f}=1)$ ve olumlu etki ( $\mathrm{f}=1$ ) kodları bulunmaktadır. Bu kodlarda öğretmenler STEM eğitiminin olumlu etkiler oluşturduğunu, öğrencilerin katılım, motivasyon ve özgüvenlerini artırdığını ifade ederek bunlar hakkında gözlemlerini belirtmişlerdir. Etkinliklerin çocukların dikkatlerini çekerek algıları açık bir şekilde derse odaklandıklarını, bütün öğrencilerin derse olan aktifliklerini artırdığını, ortaya bir ürün çıkarmaları kendilerine olan güvenlerini önemli ölçüde artırdığını, evlerine gittiklerinde okulda yaptıklarını ailelerine anlattıklarını ve benzer etkinlikleri ellerinde olan malzemelerle yapmaya çalıştıklarını veliler tarafından öğretmenlere söylendiğini, bir öğretmen etkinliklerin başlarında belki erkeklerin biraz daha aktif olduğunu ama sonraları kızlarında aynı oranda katılım gösterdiklerini ifade etmişlerdir.

Alternatifler kategorisinde; dokunma duyusu $(\mathrm{f}=1)$, uygulama $(\mathrm{f}=1)$ ve teoriden uzaklaşma ( $\mathrm{f}=1$ ) kodları bulunmaktadır. Bu kodlarda öğretmenler STEM eğitiminin sağladığı alternatiflerin öğrenciler üzerinde oluşan olumlu etkilere sebep olduğunu belirtmişlerdir. Bunlar STEM eğitiminde normal eğitimden farklı ve fazla olarak çocuğun dokunarak yani yaparak yaşayarak bizzat kendisi uygulayarak öğrenme sağladığını, derslerde teori kısımlarının daha az olması sebebiyle sıkılmamalarını, farklı farklı robotlar tasarlamaları için fırsat vermesi ve ortaya güzel ürünler çıkardıklarını görmeleri etkili olduğunu ifade etmişlerdir.

\section{Veliler ile yapılan görüşme sonuçları}

STEM Eğitiminin öğrenci üzerindeki tutum ve davranışlarına etkisinin veli tarafindan değerlendirilmesini içeren, "Çocuğunuzun Almış Olduğu Ĕ̆itim Sonucunda Evde Herhangi Bir Etkinlik Yapmak Istedi Mi? Evetse Neler Mesela?”, “Çocuğunuzun Almış Olduğu Bu 
Eğitimin Çocuğunuzda Bir Etkisinin Olduğunu Düşünüyor Musunuz? Evetse Nasıl?”, , “Çocuğunuzun Almış Olduğu Eğitime Yönelik Tutum Ve Davranışları Nasıldı? Bununla İlgili Bir Şeyler Gözlemlediniz Mi? Nasıl?” sorularının cevaplarının analizi tablo 1 de yorumlanıştır.

Tablo 1.

STEM Eğitiminin öğrenci üzerindeki tutum ve davranışlarına etkisinin veli tarafindan değerlendirilmesi

\begin{tabular}{llr}
\hline Kategori & \multicolumn{1}{c}{ Kod Adı } & Frekans (F) \\
\hline \multirow{2}{*}{ Aileye Aktarma } & Robot yapma & 4 \\
& Süreci anlatma & 4 \\
& İlgili programlar izlemek & 2 \\
\hline \multirow{2}{*}{ Çocuğa etkisi } & Yaratıcılık & 1 \\
& Fayda sağlama & 1 \\
\hline \multirow{2}{*}{ Evde Etkinlik } & Öğrendiğini uygulama & 2 \\
& Farklı şekiller yapma & 1 \\
& Birleştirme-yapıştırma & 1 \\
\hline \multirow{2}{*}{ Tutum-Davranış } & Bahsetmek & 3 \\
& Yardım etmek & 1 \\
& Robotlar yapmak & 1 \\
\hline & Yaratıcilık & 3 \\
STEM Eğitiminin Faydaları & Konuda yetkinlik & 1 \\
& Üretkenlik & 1 \\
& Gelişim & 1 \\
\hline \multirow{2}{*}{ Duygu-Düşünce } & Ön bilgi & 1 \\
& Sevmek & 8 \\
\hline Toplam & Beceriyi & 1 \\
\hline
\end{tabular}

Tablo 1' de görüşme sonucu velilerin soruya yönelik cevaplarına yer verilmiş ve 6 ayrı kategori ortaya çıkmıştır. Aileye aktarma kategorisinde; robot yapma ( $\mathrm{f}=4)$, süreci anlatma $(\mathrm{f}=4)$ ve ilgili programlar izlemek $(\mathrm{f}=2)$ kodları bulunmaktadır. En fazla frekans süreci anlatma koduna aittir. Bu kodlarda bütün veliler çocuklarının okulda yaptıkları STEM etkinliklerini evde kendilerine anlattıklarını ifade etmişlerdir. Anlattıkları bilgiler arasında, robotlar yapıp çalıştırdıklarını, eğitim için abi ve ablaların (eğitimi veren uzmanlar) geldiğini ve onlara yardım ettiklerini, arkadaşlarıyla birlikte grupça etkinlikler yaptıklarını anlatmışlardır. Ayrıca bazı veliler çocuklarının bu eğitimden sonra televizyonda robotla ilgili programlar izlemeye başladıklarını ifade etmişlerdir.

Çocuğa etkisi kategorisinde; yaratıcılık (f=1) ve fayda sağlama ( $\mathrm{f}=1)$ kodları bulunmaktadır. Bu kodlarda veliler STEM eğitiminin çocuklarına sağladığı olumlu etkilerden bahsetmişlerdir. Bazı veliler çocuklarının zaten bu tarz etkinlikleri çok sevdiklerini ve bu 
eğitimle kendilerini geliştirdiklerini, yaratıcılıklarını artırarak fayda sağladığını ifade etmişlerdir.

Evde etkinlik yapma kategorisinde; öğrendiğini uygulama ( $\mathrm{f}=2$ ), yapmaya çalışma $(\mathrm{f}=2)$, farklı şekiller yapma $(\mathrm{f}=1)$ ve birleştirme-yapıştırma $(\mathrm{f}=1)$ kodları bulunmaktadır. $\mathrm{Bu}$ kodlarda veliler çocuklarının evde eğitimden sonra yaptıklarından bahsetmişlerdir. Bunlar, öğrendiklerinin aynısını elinde bulunan malzemelerden kendileri yapmaya çalıştıklarını, kağıtlarda farklı şekiller kesip yapıştırdıklarını bunları birleştirerek yeni ürünler oluşturduklarını belirtmişlerdir. Bir veli ise çok yapmadığını ifade etmiştir.

Tutum-davranış kategorisinde; bahsetmek ( $\mathrm{f}=3)$, yardım etmek $(\mathrm{f}=1)$, önceden anlatmamak $(\mathrm{f}=1)$ ve robotlar yapmak $(\mathrm{f}=1)$ kodları bulunmaktadır. Bu kodlarda veliler çocuklarının tutum ve davranışlarında oluşan değişimin iyi yönde olduğunu, çocuklarının önceden okulda yaptıklarından hiç bahsetmediklerini fakat bu eğitimden sonra her hafta ne yaptıklarını söylediklerini, çok hoşlarına gittiğini, robotlar yaptıklarını ve bunların çok güzel olduğunu, birbirlerine yardım ettiklerini ve eğitimi veren abi ablalarla birlikte yaptıklarını bahsettiklerini belirtmişlerdir.

Duygu-düşünce kategorisinde; beceri ( $f=1$ ), ön bilgi ( $f=1)$ ve sevmek ( $f=3$ ) kodlar1 bulunmaktadır. Bu kodlarda veliler çocuklarının verilen eğitimde yaptıklarını çok sevdiklerini, hoşlarına gittiğini ve mutlulukla bahsettiklerini ifade etmişlerdir. Çocuklarının bu tarz etkinlikleri yaparken artık ön bilgilere sahip oldukları için daha yetkin şekilde değişik şeyler oluşturduklarını ve çok sevdiklerini ifade etmişlerdir. Ayrıca çocukların bu alan yönelik ilgi ve becerilerini artırdığını belirtmişlerdir.

STEM eğitiminin faydaları kategorisinde; yaratıcılık $(f=3)$, konuda yetkinlik $(f=1)$, üretkenlik $(\mathrm{f}=1)$ ve gelişim $(\mathrm{f}=1)$ kodları bulunmaktadır. Bu kodlarda veliler eğitimin çocuklarını geliştirdiğini, üretkenliğini artırdığını, evde farklı farklı ürünler, şekiller oluşturmaya başladıklarını, yaratıcılıklarını daha da geliştirdiğini, etkinliklerde daha yetkin olmaya başladıklarını belirtmişlerdir. Veliler çocuklarının STEM eğitimi ile okulda yapılan normal eğitimin dışında farklı şeyler görmelerinin olumlu olduğuna yönelik görüşlerini belirtmişlerdir.

Velilerin STEM Eğitimine yönelik görüşlerini içeren, "Sizce Okullarda Bu Tarz Eğitimler Verilmeli Mi? Neden?” ve "Sizce Çocuğunuzun Almış Olduğu Bu Eğitimin Okullardaki Normal Eğitimden Farkı Var Mı?" sorulara verdikleri cevapların analizleri tabloda yorumlanmıştır.

Tablo 2. 
STEM Ĕ̈itimine İlişkin Veli Görüşleri

\begin{tabular}{llr}
\hline Kategori & \multicolumn{1}{c}{ Kod Adı } & Frekans (F) \\
\hline \multirow{2}{*}{ STEM Eğitiminin Farkı } & Ayrıntılı & 2 \\
& Uygulamaya dönük & 3 \\
& Heves uyandırıcı & 1 \\
& Geliştirici & 1 \\
\hline \multirow{2}{*}{ İletişìm } & Sosyalleşme & 1 \\
& İçine kapanıklık & 1 \\
\hline \multirow{2}{*}{ STEM Eğitimine Yönelik Görüşs } & Verilmeli & 4 \\
& Tekrar edilmeli & 1 \\
& Çok faydalı & 1 \\
\hline & Görsel algı & 1 \\
Çocuklar Üzerindeki Etkisi & El becerisi & 1 \\
& Öğrenme dönemleri & 2 \\
& Gelişim dönemleri & 2 \\
\hline Toplam & & 17 \\
\hline
\end{tabular}

Tablo 2' de görüşme sonucu velilerin soruya yönelik cevaplarına yer verilmiş ve 6 ayrı kategori ortaya çıkmıştır. STEM eğitiminin farkı kategorisinde; ayrıntılı $(f=2)$, uygulamaya dönük ( $\mathrm{f}=3$ ), heves uyandırıcı ( $\mathrm{f}=1$ ) ve geliştirici ( $\mathrm{f}=1$ ) kodları bulunmaktadır. Bu kodlarda veliler, STEM eğitiminin okulda verilen normal eğitimden farklarından bahsetmişlerdir. STEM eğitiminin daha ayrıntılı ve birebir uygulamaya daha çok dönük olduğunu, teorik kısmın normal eğitime göre daha az olduğunu, daha değişik faaliyetler yapıldığını, çocuklarının heves ve ilgilerini çok artırdığını ve onlardaki gelişimi artırdığı gibi farkları belirten ifadelere yer verilmiştir.

İletişim kategorisinde; sosyalleşme $(\mathrm{f}=1)$ ve içine kapanıklık (f=1) kodları bulunmaktadır. Bu kodlarda veliler çocuğunun içine kapanık biri olduğunu ve bu eğitimden sonra çok sosyalleştiğini fark ederek iletişim gelişimini dikkate alarak farkı belirtmişlerdir.

STEM eğitimine yönelik görüş kategorisinde; verilmeli $(f=4)$, tekrar edilmeli $(f=1)$ ve çok faydalı $(\mathrm{f}=1)$ kodları bulunmaktadır. Bu kodlarda veliler verilen eğitimin çocukları için çok faydalı ve farklı bir eğitim olarak bulduklarını, çocukların tam gelişme gösterdikleri bir dönemde oldukları için bu eğitimin verilmesi ve tekrarının olması gerektiğini ifade etmişlerdir.

Çocuklar üzerindeki etkisi kategorisi; görsel algı ( $\mathrm{f}=1$ ), el becerisi ( $\mathrm{f}=1$ ), öğrenme dönemleri ( $\mathrm{f}=2$ ) ve gelişim dönemleri $(\mathrm{f}=2)$ kodları bulunmaktadır. Bu kodlarda bazı veliler eğitimin çocukları üzerinde bıraktığı etkileri belirterek verilmesi gerektiğini ifade etmişlerdir. Çocukların öğrenme ve gelişim dönemlerinde olması sebebiyle STEM eğitiminin çocuklarındaki el becerilerini ve görsel algılarını geliştirdiğini gözlemlediklerini belirterek tekrar verilmesini istemişlerdir. 


\section{Tartışma}

Sonuç olarak okul öncesinde yapılan tasarım temelli STEM eğitimlerinin öğretmen ve veli gözlemleri doğrultusunda öğrenciler üzerinde olumlu etkiler ve davranışlar oluşturduğunu ve eğitimin hem sisteme hem de öğrenci seviyesine uygun olduğu tespit edilmiştir.

Çalışma sonuçları arasında öğretmen görüşlerine göre tasarım temelli STEM eğitiminin çocukların resim çizme ve mühendislik tasarımı becerilerinde gözle görülür oranda gelişmeler gösterdikleri belirtilmiştir. Ayrıca ince motor kaslarının ve el becerilerini de geliştirdiğini, derse yönelik ilgilerinin arttığını, bilgilerin uygulamaya dönük olması kalıcılı̆̆ı sağladığını, akademik anlamda başarı duygusunu, motivasyon, özgüvenlerini artırdığını ve ürün oluşturma yeteneklerini geliştirdiğini, olumlu tutumlar oluşturduğunu ifade etmişlerdir. Aynı şekilde veli görüşleri sonuçları da çocuklarının eğitimi dikkat çekici bulduklarını, robotlara ve mühendislik tarzı tasarımlara yönelik ilgilerinin arttığını ifade etmiş̧lerdir. Çalışma sonucunu destekler nitelikte Akgündüz ve Akpınar (2018) çalışmalarında, okul öncesinde STEM eğitimine yönelik öğretmen, öğrenci ve veli görüşlerini incelemişler ve benzer sonuçlara yer vermişlerdir. Çalışmalarında uygulanan STEM etkinliklerinin öğretmen görüşleri doğrultusunda, çocuğun mühendislik ve tasarım çizme becerilerini, ince ve kaba motor becerileri geliştirdiğini ve el-göz koordinasyonlarını olumlu yönde etkilediğini ifade etmişlerdir. Sarı vd. (2020) yaptıkları çalışma sonucunda STEM eğitiminin öğrencilerin bilimsel süreç becerilerini, derse karşı tutum ve motivasyonlarını artırdığını belirtmişlerdir. STEM eğitimi birbirine entegre edilmiş disiplinlerle akademik ilerlemeyi sağladığı gibi aynı zamanda mühendislik tasarımı gibi sistematik problem çözme ve ürün elde etme yeteneklerini de geliştirdiğini ifade etmişlerdir (Akgündüz ve Akpınar, 2018; Yıldırım ve Türk, 2018). Yine Koyunlu Ünlü ve Dere (2019), okul öncesi öğretmen adaylarının STEM farkındalıklarını değerlendirmeyi amaçlayan çalışmalarında STEM eğitiminin öğrenciye yönelik olumlu etkileri olacağını belirten öğretmen adayı görüşlerine yer vermiş̧lerdir. Alan (2020) okul öncesinde uygulanan havacıllk ve uçaklar temalı STEM eğitimi isimli çalışmasında öğretmen ve veli görüşmeleri sonuçlarında bu programın çocukların ince motor becerilerinin gelişimine katkı sağladığı ortaya koymuştur. Çalışma sonucunda öğretmen ve veliler, STEM eğitiminin çocukları farklı fikirler üretmelerini sağladığını, STEM' e yönelik ilgi ve tutumlarının olumlu olarak arttı̆̆ı, derse karşı başarılarındaki motivasyonlarını artırdığını belirtmişlerdir. Sonuçları destekler nitelikte Gökbayrak ve Karışan (2016) çalışmalarında, STEM uygulamalarının öğrencilerin ilgi ve motivasyonlarını arttırdığını ifade etmişlerdir. Yıılııım (2016) çalışması da STEM eğitimin 
öğrencilerin motivasyonları üzerine olumlu etki yaptığını tespit etmiştir. STEM uygulamalarının öğrencilerin motivasyonlarını arttırmada önemli etkisi olduğunu gösteren benzer çalışmalar bulunmaktadır (Green, 2012; Kang , Ju ve Jang, 2013; Özdoğru, 2013; Park ve Yoo, 2013). Yıldırım ve Selvi (2017), STEM uygulamaları ve tam öğrenmenin ortaokul öğrencilerinin akademik başarılarına, fene yönelik algılarına ve motivasyonlarına, STEM'e karşı tutumlarına ve bilginin kalıcılığına olan etkisini incelemiştir. Sonuç olarak STEM uygulamalarının öğrencilerin derse yönelik motivasyonlarını arttırdığını belirtmişlerdir. Cosentino (2008), Green (2012), Hill (2002), Kang, Ju ve Jang (2013); araştırmalarında STEM etkinliklerinin öğrencinin akademik başarısını artırdığına dair sonuçlara yer vermişlerdir. Çevik ve Abdioğlu (2018) ise bir bilim kampının 8. sınıf öğrencilerinin STEM başarılarına, fen motivasyonlarına ve üstbilişsel farkındalıklarına etkisini incelemişlerdir. Sonuç olarak STEM etkinliklerinin başarıyı anlamlı düzeyde artırdığını ve STEM başarısı ile fen motivasyonu arasında yüksek düzeyde bir korelasyonun olduğunu ortaya koymuşlardır. Hartzler (2000) çalışmasında, mühendislik tasarımı dikkate alınarak öğretilen matematik ve fen etkinliklerinin, öğrencinin derse ilgisini, öğrenme isteğini ve başarısını artırdığı sonucuna ulaşması araştırma sonuçlarını desteklemektedir. Yine Doppelt et al. (2008) çalışmasında STEM eğitiminin öğrencilerin fene yönelik ilgisinin, öğrenme arzusunun ve başarının artmasında oldukça önemli bir yere sahip olduğunu belirtmişlerdir.

Çalışma sonucunda öğretmenler, STEM eğitiminin öğrencilerin tutumunda olumlu etkiler oluşturduğunu, yapılan etkinliklerin erkeklere biraz daha hitap etmesine karşın kız öğrencilerin tutumlarının erkekler kadar hatta bazen daha fazla olumlu tutum içinde olduklarını belirtmişlerdir. Ayrıca yine veliler ve öğretmenler, STEM uygulamalarının öğretim programlarında daha uzun süreyle yer verilmesinin bu tutumu artıracağını ve çocuk için faydalı olacağını belirtmişlerdir. Yıldırım ve Türk (2018), STEM uygulamalarının kız öğrencilere yönelik STEM tutum ve mühendislik algılarını incelemişlerdir. Ulaştıkları sonuçlar çalışmayı desteklemektedir. Bunlar, STEM uygulamalarının kız öğrencilerin STEM'e yönelik tutumlarını geliştirmede etkili olduğunu tespit etmişlerdir. Ayrıca STEM uygulamalarına öğretim programlarına daha fazla yer verilmesini ve kız öğrencilerle daha fazla STEM çalışmalarının yapılmasını önemle vurgulamışlardır. Yine çalışma sonuçları arasında bazı çocukların içine kapanık olduğunu ve bu eğitimden sonra çocukların sosyalleşme becerilerinin, iletişim kurma gibi becerilerinin geliştiği ifade edilmiştir. Sonuçları destekler nitelikte, Bagiati (2011) mühendislik tabanlı STEM eğitimi çalışmasında çocukların eğitim sonrasında sözlü iletişim ve düşüncelerini ifade etme becerileri sergilediklerini belirtmiştir. Lippard ve arkadaşları (2019) 
anaokulu çocuklarının mühendislik etkinlikleri süresince birbirleriyle iletişim kurma becerilerini gösterdiklerini belirtmiştir. Dorouka ve arkadaşları (2020) STEM çalışmalarında, erken çocukluk eğitiminde STEM eğitimi ve okuryazarlığı teşvik eden tabletler ve robotik uygulamalarının olumlu yönde etkisini belirtmiştir. Timur vd. (2020) okul dışı STEM eğitimine katılan öğrencilerin STEM' e yönelik tutumlarını araştırmışlardır. Sonuç olarak çocukların yaparak yaşayarak öğrenmeler gerçekleştirmeleri STEM' e yönelik olumlu tutumlar sergiledikleri tespit edilmiştir.

Çalışmadaki eğitimden sonra öğretmenler ve veliler çocukların fikirlerinde üretme, farklılaşmalar, şekillenmeler gibi zihinsel aktivite anlamında gelişimler gösterdiklerini belirtmişlerdir. Ayrıca yaratıcılık ve problem çözme gibi bilimsel süreç becerilerinin de geliştiğini vurgulamışlardır. Alan (2020) STEM çalışmasında eğilim kavramını zihin alışkanlıkları veya belirli durumlara belirli şekillerde cevap verme yatkınlığı olarak tanımlamış ve çalışmasında gerçekleştirilen STEM eğitimi ile çocukların genel olarak ilgi kaynaklı bazı eğilimler geliştirdikleri sonucuna ulaşılmıştır. Mantzicopoulos ve arkadaşları (2013), erken dönemde, uygun ve devamlı katılımı teşvikeden bilimsel uygulamaların çocukların bilime yönelik ilgilerini olumlu yönde beslediğini vurgulamıştır. Şahin ve Yıldırım (2006), yaptıkları çalışmada fen etkinlikleri ile çocukların bilimsel sorgulama, planlama, planı gerçekleştirme ve problem çözme becerilerinde, yaratıcılıklarında artış gözlemlemişlerdir. Stoll ve diğerlerinin (2012) yaptıkları çalışmaya göre basit araçların kullanıldığı STEM etkinliklere katılan çocukların, normal eğitime göre problem çözme becerilerinin daha yüksek olduğunu vurgulamışlardır. Uysal ve Cebesoy (2020) çalışmalarında, tasarım temelli STEM etkinliklerinin öğretmen adaylarının bilimsel süreç becerini ve tutumlarını geliştirdiğini tespit etmişlerdir.

Ceylan (2014) çalışmasının sonuçlarında STEM eğitiminin öğrencilerin yaratıcılık ve problem çözme becerilerini geliştirdiğini ifade ederek araştırma sonuçlarını desteklemektedir. Yıldırım (2016) STEM eğitiminin öğrenciler üzerindeki yaratıcılık, problem çözme gibi becerileri üzerindeki tutum ve etkiyi belirlemek amacıyla STEM eğitimi ile ilgili yapılan 33 çalışmanın analizini yapmıştır. Sonuç olarak çalışmalarda STEM eğitiminin öğrenci başarısını ve bilimsel becerilerini artırdığı, olumlu yönde tutum ve etkileri sağladığı da tespit edilmiştir.

Çalışmada öğretmen görüşleri doğrultusunda STEM eğitiminin verilmesi gereken en uygun dönem gelişimin en verimli olduğu okul öncesi dönem olduğu sonucuna ulaşılmıştır. Çalışma sonucunu destekler nitelikte olan Balat ve Günşen (2017), okul öncesi dönemde STEM eğitimini açıklayarak veli ve eğitmenlere yönelik önerilerde bulunma amaçlı çalışmalarında, yürütücü işlev becerilerinin en çok okul öncesi dönemde geliştirildiği ve 7 yaşında gelişimin 
büyük oranda tamamlandığını belirtmişlerdir. Bu sebeple STEM eğitiminin verileceği en uygun dönem olarak çocuğun en çok araştırma ve gelişim dönemi olan okul öncesinde verilmesi gerektiğini ifade etmişlerdir. Yine sonuçlar arasında öğretmenler, STEM eğitimi kapsamında çocukların çok farklı etkinlikler gördüklerini ve bu farklılığa gelişim ve değişim için gerekli olduğunu belirtmişlerdir. Torres-Crospe, Kraatz and Pallansch (2014) çalışmalarında, okul öncesi çocuklar için düzenlediği STEM kampında mühendislik etkinliklerine yer vermişlerdir. Ve okul öncesi dönemde çocukların akademik becerilerinin gelişimi kadar çocukların farklı etkinlikler ve stratejiler ile ilgili farkındalık kazanmalarının da önemli olduğunu ifade etmişlerdir.

Çalışma sonuçlarında öğretmenlerle yapılan görüşmede eğitimin çocukların mesleki gelişimlerini de etkisi olduğunu belirtmişlerdir. Bazı çocukların ilerde mühendis ve astronot olmak istediklerini belirtmişlerdir. Çalışma sonucunu destekler nitelikte Peterson (2018) tasarım tabanlı STEM eğitimi sürecinin 5. sınıf çocuklarının bilime yönelik mesleklere olan ilgisinde anlamlı bir oluşturduğunu belirtmiştir. Çiftçi (2018) STEM etkinlilerinin ortaokul öğrencileri üzerindeki yaratıcılık düzeyi, disiplinleri anlama ve meslekleri fark etme isimli araştırmasının sonucunda öğrencileri aldıkları eğitimden sonra seçtikleri mesleklerin teknoloji ve fen içerikli mesleklere yöneldiğine ulaşılmıştır.

Çalışmada öğretmen ve veli ortak görüşlerinde eğitime yönelik çocukların duygu ve düşünce olarak olumlu etkilerinden bahsetmişlerdir. Çocukların eğitimi çok sevdiklerini, mutluluk, heyecan, şaşkınlık, özgüven gibi duygularının geliştiğini ve eğlenceli vakit geçirdiklerini belirtmişlerdir. Destekler nitelikte Alan (2020) de okul öncesinde yapılan STEM çalışması sonuçlarında öğretmen ve veli görüşlerinin çocukların genel olarak tüm uygulama sürecinde olumlu duygulara sahip olduklarını, çocukların süreç boyunca belirgin olarak mutluluk, şaşkınlık, heyecan ve kendine güven duygularını yansıttıklarını vurgulamıştır. Yine Bagiati'nin (2011) ve Ata-Aktürk'ün (2019) da yaptıkları çalışmalarında aynı sonuçlara ulaşmışlardır. Durkin (2018) okul öncesinde STEM eğitiminin işbirlikli öğrenmeye etkisini içeren çalışmasında çocukların STEM etkinliklerine heyecanla katıldıklarını aktarmıştır. İyi bir eğitimin de öğretim sürecinde öğrencilerin olumlu duygular oluşturulması önemle vurgulanmaktadır (Hargreaves, 2005).

Çalışmada veli ve öğretmen görüşleri kapsamında çocukların okul dışında da eve gittiklerinde eğitim kapsamında olan etkinliklere yöneldikleri tespit edilmiştir. Öğrendiklerini evde bulunan farklı materyallerle başka tasarımlar uluşturarak geliştirdiklerini ifade etmişlerdir. Ata-Aktürk (2019) çalışmasında okulda mühendislik etkinlikleri gerçekleştiren çocukların ev 
ortamında da mühendislik etkinlikleri gerçekleştirmeye başladıklarını çalışma sonucunda vermiştir. Yine Tippett ve Millford (2017) çalışmasında çocuklara verilen STEM eğitimi sonrasında çocukların okul dışı ortamlarda daha fazla STEM etkinliği gerçekleştirdiklerini bulmuştur. Çünkü Young, Ortiz ve Young (2017) ye göre okul dışı yapılan STEM etkinliklerinin öğrenenlere çeşitli firsatlar sunduğunu ve STEM'e yönelik ilgiyi artırdığını, beceri kazandırdığını ifade etmiştir.

Çalışmada öğretmenler STEM eğitimine yönelik Türk eğitim sistemine gayet uygun olduğunu; bu alana derslerde daha çok zaman verilerek, öğretmenlere bu alanlarda eğitimler verilerek, gerekli materyal ve ortamlar MEB tarafından sağlanarak uygulanmasının çok güzel olacağını belirtmişlerdir. Sonucu destekleyen Uğraş (2017) okul öncesi öğretmenlerin STEM' e yönelik görüşlerini incelemiş ve öğretmenlerin diğer disiplinler ile ilgili bilgi eksikliği, hizmet içi eğitim eksikliği, zaman sıkıntısı, uygulamaların masraflı olması ve yeterli bilincin oluşmamış olması ve bunların giderilmesi sonucu çağın ihtiyacı olan bireylerin yetiştirilmesinde STEM eğitiminin önemli bir role sahip olduğunu belirtmiştir. 


\section{Kaynakça}

Adıgüzel, T., Ayar, M. C., Corlu, M. S. \& Özel, S. (2012). Fen, teknoloji, mühendislik ve matematik eğitimi: Disiplinler arası çalışmalar ve etkileşimler. 10. Ulusal Fen Bilimleri ve Matematik Eğitimi, Niğde, Turkey.

Akgündüz, D. \& Akpınar, B. C. (2018) . Okul öncesi eğitiminde fen eğitimi temelinde gerçekleştirilen STEM uygulamalarının öğrenci, öğretmen ve veli açısından değerlendirilmesi. Yaşadıkça Eğitim, 32(1), 126.

Alan, Ü. (2020). Okul öncesi dönem çocuklarına yönelik geliştirilen STEM eğitimi programının etkililiğinin incelenmesi. Hacettepe Üniversitesi Eğitim Bilimleri Enstitüsü, Doktora Tezi. Ankara.

Allen, A. (2016). Don't fear STEM you already teach it. School Age/After School Exchange, September/October, 56-59.

Ata-Aktürk, A. (2019). Development of a STEM based engineering design curriculum for parental involvement in early childhood education. Doctoral dissertation. Middle East Technical University, Ankara.

Altun Yalçın, S., \& Yalçın, P. (2018). Fen bilgisi öğretmen adaylarının STEM eğitimi konusundaki metaforik algilarınin incelenmesi. International Journal of Social Science, 70, 39-59.

Aral, N., Yıldız Bıçakcı, M., Yurteri Tiryaki, A., Çetin Sultanoğlu, S. \& Şahin, S. (2015). Montessori eğitiminin çocukların gelişimine etkisinin incelenmesi. Hacettepe Üniversitesi Eğitim Bilimleri Enstitüsü Eğitim Araştırmaları Dergisi, 1(1).

Arastaman, G., Öztürk Fidan, İ. \& Fidan, T. (2018). Nitel araştırmada geçerlik ve güvenirlik: kuramsal bir inceleme, YYÜ Eğitim Fakültesi Dergisi, 15(1):37-75.

Aytaçlı, B. (2012). Durum çalışmasına ayrıntılı bir bakış. Adnan Menderes Üniversitesi Eğitim Fakültesi Eğitim Bilimleri Dergisi, 3 (1), 1-9.

Bagiati, A. (2011). Early engineering: A developmentally appropriate curriculum for young children (Doctoral dissertation). Available from ProQuest Dissertation and Thesis Database. (Order No. 3512219).

Bybee, R. W. (2010b). Advancing STEM education: A 2020 vision. Technology and Engineering Teacher, 70(1), 30-35.

Ceylan, S. (2014). Ortaokul fen bilimleri dersindeki asitler ve bazlar konusunda fen, teknoloji, mühendislik ve matematik (FeTeMM) yaklaşımı ile öğretim tasarımı hazırlanmasına yönelik bir çalışma. Yüksek Lisans Tezi, Bursa Uludağ Üniversitesi Eğitim Bilimleri Enstitüsü, 172-206.1

Cosentino, C. (2008). The Impact of integrated programming on student attitude and achievement in grade 9 academic mathematics and science. Master's Thesis. Brock University, Ontario.

Creswell, J. W. (2002). Educational research: Planning, conducting, and evaluating quantitative and qualitative research. Upper Saddle River, NJ: Columbus, Ohio. 
Çakır, Z., Yalçın, S. A., \& Yalçın, P. (2019). Montessori yaklaşımı temelli STEM etkinliklerinin okul öncesi ögretmen adaylarının yaratıcılık becerilerine etkisi. Journal of the International Scientific Research, $4(2), 392-409$.

Çepni, S. (2017). Kuramdan uygulamaya STEM+A+E eğitimi. 1. Baskı. Ankara: Pegem Akademi.

Çevik, M. \& Abdioğlu, C. (2018). Bir bilim kampının 8. sınıf öğrencilerinin STEM başarılarına, fen motivasyonlarına ve üstbilişsel farkındalıklarına etkisinin incelenmesi. İnsan ve Toplum Bilimleri Araştırmaları Dergisi, 7 (5), 304-327.

Çolakoğlu, M. \& Günay Gökben, A. (2017). Türkiye'de eğitim fakültelerinde FeTeMM (STEM) çalışmaları. İnormal Ortamlarda Araştırmalar Dergisi, 2 (2), 46-69.

Diamond, A. \& Lee, K. ( 2011). Interventions shown to aid executive function development in children 4-12 years old. Science Journal, 333(6045), 959-964.

Dorouka, P., Papadakis, S. \& Kalogiannakis, M. (2020).Tablets and apps for promoting robotics, mathematics, STEM education and literacy in early childhood education. International Journal of Mobile Learning and Organisation, 14(2).

Doppelt, Y., Mehalik, M. M., Schunn, C. D., Silk, E. \& Krysinski, D. (2008). Engagement and achievement: A case study of desing- based learning in a science context. Journal of Technology Education, 19(2), 22-39.

Durkin, A. (2018). Can providing young children with opportunities to participate in STEM activities encourage cooperative learning? (Master's thesis). Available from ProQuest Dissertation and Thesis Database. (Order No. 13424228).

Gökbayrak, S. \& Karışan, D. (2017). Altıncı sınıf öğrencilerinin FeTeMM temelli etkinlikler hakkındaki görüşlerinin incelenmesi. Alan Eğitim Araştırmaları Dergisi, 3(1), 25-40.

Green, A. (2012). The integration of engineering design projects into the secondary science classroom. Master's Thesis. Michigan State University, Michigan.

Gropen, J., Clark-Chiarelli, N., Hoisington, C. \& Ehrllich, S. (2011). The importance of executive function in early science education. Child Development Perspectives, 5(4), 298-304

Hadzigeorgiou, Y. (2002). Okul öncesi çocuklarda mekanik stabilite kavramının gelişimi üzerine bir çalışma. Fen Eğitimi Araştırmaları, 32(3), 373-391.

Hartzler, D. S. (2000). A meta-analysis of studies conducted on integrated curriculum programs and their effects on student achievement. (Doktora Tezi) Indiana Universitesi, ABD.

Hill, M.D. (2002). The effects of integrated mathematics/science curriculum and instruction on mathematics achievement and student attitudes in grade six. Doctoral Dissertation. Texas A\&M University, Texas.

Kang, J., Ju, E.J. \& Jang, S., (2013). The Effect of Science-based STEAM program using a portfolio on elementary students' formation of science concepts. Elementary Science Education, 32(4), 593-606.

Katz, L. G. (2010). STEM in the early years. SEED papers, Retrieved November, 3. 
Kaya, D. \& Gündüz, M. (2015). Alternatif eğitim ve toplumsal değişim üzerindeki etkisi: Waldorf Okulları Örneği. MEB Dergisi, 205.

Koyuncu, A. \& Kırgız, H. (2016). Bilim merkezlerinin öğrencilerin uluslararası sınavlardaki başarılarına etkisi. İnformal Ortamlarda Araştırmalar Dergisi, 1(1), 52-60.

Koyunlu Ünlü, Z. \& Dere, Z. (2018). Okul öncesi öğretmen adaylarının hazırladıkları FeTeMM etkinliklerinin değerlendirilmesi. Kırşehir Eğitim Fakültesi Dergisi, 19(2), 1502- 1512.

Koyunlu Ünlü, Z. \& Zeynep Dere, Z. (2019). Okul öncesi öğretmen adaylarının FeTeMM farkındalıklarının değerlendirilmesi. Erzincan Üniversitesi Eğitim Fakültesi Dergisi, 21(1), Doi numaras1: 10.17556/erziefd.481586.

Lippard, C. N., Lamm, M. H., Tank, K. M., \& Choi, J. Y. (2019). Pre-engineering thinking and the engineering habits of mind in preschool classroom. Early Childhood Education Journal, 47(2), 187-198.

MEB, (2013). PISA 2012 Ulusal Ön Raporu. Ankara.

Meyrick, K. M. (2011). How STEM education improves student learning. Meridian K12 School Computer Technologies Journal, 14(1), 1-6.

Morrison, J. S. (2006). Ties STEM education monograpy series attributes of STEM education the student, the Academy, the classroom. Copyrigth ties.

Mutlu, B., Ergişi, A., Ayhan, A. \& Aral, A. (2012). Okul öncesi dönemde Montessori eğitimi. Ankara Sağlk Bilimleri Dergisi, 1(3), 113-12.

Özdoğru, E. (2013). Fiziksel olaylar öğrenme alanı için lego program tabanlı fen ve teknoloji eğitiminin öğrencilerin akademik başarılarına, bilimsel süreç becerilerine ve fen ve teknoloji dersine yönelik tutumlarına etkisi. Yüksek lisans tezi. Dokuz Eylül Üniversitesi, İzmir.

Park, S.J. \& Yoo, P.K., (2013). The Effects of the learning motive, interst and science process skills using the "Light" unit in science-based STEAM. Elementary Science Eucation, 32(3): 225-238.

Peterson, B. M. (2018). Applying curriculum treatments to improve STEM attitudes and promote STEM career interest in fifth graders (Doctoral dissertation). Virginia Tech, Virginia.

Polat, Ö. \& Bardak, M. (2019). STEM approach in early childhood in Turkey. International Journal of Social Science Research, 8(2), 18-41.

Sarı, U., Duygu, E., Şen, Ö. F., \& Kırındı, T. (2020). The Effect of STEM Education on Scientific Process Skills and STEM Awareness in Simulation Based Inquiry Learning Environment. Journal of Turkish Science Education, 17(3), 387-405.

Stoll, J., Hamilton, A., Oxley, E., Eastman, A. M. \& Brent, R. (2012). Young thinkers in motion: Problem solving and physics in preschool. Young Children, 67(2), 20-26. 
Şahin, F. \& Yıldırım, M. (2006). Okul öncesinde örnek olaya dayalı problem çözme ile ilgili bir araştırma. I. Uluslararası Okul Öncesi Eğitim Konferansı, 30 Haziran-3 Temmuz 2004, Bildiri Kitabı-1 (s.201210), İstanbul: Yapa.

Tepeli, K. \& Yılmaz, E. (2012). Üç farklı programa göre eğitim alan okul öncesi çocukların sosyal kural algılarının incelenmesi. Selçuk Üniversitesi Sosyal Bilimler Enstitüsü Dergisi, (28).

Torres-Crospe, M. N., Kraatz, K. \& Pallansch, L. (2014). From fearing STEM to playing with it: The natural integration of STEM into the preschool classroom. SRATE Journal, 23(2), 8-16.

Timur, S., Timur, B., Yalçınkaya-Önder, E., \& Küçük, D. (2020). Okul dışı STEM çalıştaylarına katılan öğrencilerin stem eğitimine yönelik tutumları. Kuramsal Eğitim Bilimleri Dergisi, 13(2).

Tippett, C. D. \& Milford, T. M. (2017). Findings from a pre-kindergarten classroom: Making the case for STEM in early childhood education. International Journal of Science and Mathematics Education, 15(1), 6786.

Uğraş, M. (2017). Okul öncesi öğretmenlerinin STEM uygulamalarına yönelik görüşleri. Eğitimde Yeni Yaklaşımlar Dergisi, 1(1), 39-54.

Uysal, E. \& Cebesoy, Ü.B. (2020). Tasarım temelli STEM etkinliklerinin fen bilimleri öğretmen adaylarının bilimsel süreç becerileri, tutumları ve bilgileri üzerindeki etkisinin incelenmesi. SDU International Journal of Educational Studies, 7(1), 60-81.

Uyanık Balat, G. \& Günşen, G. (2017). Okul öncesi dönemde STEM yaklaşımı. Akademik Sosyal Araştırmalar Dergisi, 5(42), 337-348.

Yıldırım, B. (2016). 7. Sınıf fen bilimleri dersine entegre edilmiş fen teknoloji mühendislik matematik (STEM) uygulamaları ve tam öğrenmenin etkilerinin incelenmesi. Yayınlanmamış Doktora Tezi. Ankara: Gazi Üniversitesi.

Y1ldırım, B. (2020). Öğretmen yetiştirme üzerine bir model önerisi: STEM öğretmen enstitüleri eğitim modeli. Pamukkale Üniversitesi Eğitim Fakültesi Dergisi Online first, doi: 10.9779/pauefd.586603

Ylldırım, B. \& Altun, Y. (2015). STEM eğitim ve mühendislik uygulamalarının fen bilgisi laboratuvar dersindeki etkilerinin incelenmesi. El-Cezerî Fen ve Mühendislik Dergisi, 2(2), 28-40.

Yıldırım, B. (2018). Sınıf öğretmeni adaylarının tasarım temelli öğrenmeye yönelik görüşleri. Akdeniz Eğitim Araştırmalan Dergisi, 12(24), 272-293. doi: 10.29329/mjer.2018.147.15

Yıldırım, B. \& Türk, C. (2018). STEM uygulamalarının kız öğrencilerin stem tutum ve mühendislik algılarına etkisi. Adıyaman Üniversitesi Sosyal Bilimler Enstitüsü Dergisi, 843-884.

Yıldırım, B. \& Selvi, M. (2017). STEM uygulamaları ve tam öğrenmenin etkileri üzerine deneysel bir çalışma. Eğitimde Kuram ve Uygulamalar, 1(2), 183-210.

Yıldırım, A. ve Şimşek, H. (2013). Sosyal bilimlerde nitel araştırma yöntemleri. Ankara: Seçkin Yayın. 
Young, J. R., Ortiz, N. \& Young, J. L. (2017). STEM ulating interest: A meta-analysis of the effects of out-ofschool time on student STEM interest. International Journal of Education in Mathematics Science and Technology, 5(1), 62-74. 